NBER WORKING PAPER SERIES

\title{
LABOR COMPENSATION AND THE STRUCTURE OF PRIVATE PENSION PLANS: EVIDENCE FOR CONTRACTUAL VERSUS SPO'T LAABOOR MARKKET'S
}

David A. Wise

Laurence J. Kotlikoff

Working Paper No. 1290

\author{
NATIONAL BUREAU OF ECONOMIC RESEARCH \\ 1050 Massachusetts Avenue \\ Cambridge, MA 02138 \\ March 1984
}

Written for the National Bureau of Economic Research Conference on Pensions, Labor and Individual Choice, Dorado Beach, Puerto Rico, March 23-26, 1983. The research reported here is part of the NBER's research program in Pensions. Any opinions expressed are those of the authors and not those of the National Bureau of Economic Research. 
NBER Working Paper 非1290 March 1984

Labor Compensation and the Structure of Private Pension Plans:

Evidence for Contractual Versus Spot Labor Markets

\begin{abstract}
Distinguishing "spot" versus "contract" views of the labor market is of critical importance to a host of economic issues ranging from wage flexibility over the business cycle to firm financial valuation. The structural features of U.S. private pension plans permit surprisingly strong inferences concerning the incentive effects of private pension plan provisions and the contractual nature of the U.S. labor market. This paper examines the accrual of vested pension benefits of a nation-wide sample of pension plans. We find strikingly large discontinuities in the profile by age of the ratio of annual accrued pension benefits to the standard wage. These discontinuities primarily occur at the ages of full vesting and early retirement. Representative plans often exhibit absolute changes in accrual ratios of 20 to 30 percentage points at these ages. The provisions of many plans imply large negative accruals after the age of early retirement. Job change typically involves a large loss in pension wealth as well. Since the average worker's marginal product presumably changes smoothly as he or she ages, these pension data can only be reconciled with spot market clearing if age wage profiles within a firm exhibit exactly offsetting discontinuities at key ages. Casual inspection of firm wage setting behavior rules out this requirement of spot market clearing. In our view the magnitude, patterns, and variations in pension accrual ratios are strikingly at odds with spot market equilibrium. While market clearing in longer term contracts seems the only equilibrium theory consistent with these findings, it also strains our credulity to ascribe optimizing behavior to the pension accrual profiles chosen by a vast array of U.S. businesses. In the process of presenting these profiles we also consider the following questions concerning U.S. pensions. What are the incentive effects of private pension plans? What is the cost in pension benefits of job turnover? How important is vesting? Is there a cost in pension benefits of foregoing the early retirement option? Do pension stipulations encourage early retirement? While the considerable heterogeneity of pension plan provisions permits no simple or single answer to these questions, the data suggest that pensions can have major incentive effects on job turnover and retirement. In general pensions represent a very significant factor, and at certain ages, a dominant factor in employee compensation.
\end{abstract}

Laurence J. Kotlikoff

Department of Economics

Yale University

New Haven, CT 06520

David A. Wise

John F. Kennedy School of Government

79 Bolyston Street

Harvard University

Cambridge, MA 02138 
LABOR COMPENSATION AND THE STRUCTURE

OF PRIVATE PENSION PLANS: EVIDENCE FOR

CONTRACTUAL VERSUS SPOT LABOR MARKETS

\author{
by \\ Laurence J. Kotlikoff \\ and \\ David A. Wise ${ }^{1}$
}

What are the incentive effects of private pension plans? What is the cost in pension benefits of job turnover? How important is vesting? Is there a cost in pension benefits of foregoing the early retirement option? Do pension stipulations encourage early retirement? By analyzing the stipulations of pension plans, we are able to develop considerable evidence directed to these questions. At the same time, the structural features of private pension plans permit new and potentially strong inferences concerning the contractual nature of labor market agreements and the role of pensions in assisting such arrangements.

Understanding the contractual arrangements between workers and firms is important for a host of economic issues ranging from the degree of wage flexibility over the business cycle to the availability of human capital insurance within the firm. Discriminating between "spot" and "long-term contract" views of the labor market is also critical for evaluating numerous questions specific to private pensions. One such question is whether workers and employers fully appreciate how complex pension plan provisions alter a firm's total compensation package. Evidence that labor markets closely accord to the predictions of a spot market would suggest rather small information problems. Equally productive workers, in this case, receive identical total annual remuneration regardless of 
their current employer or the specifics of the employer's pension plan.

A second question involves proper disclosure and valuation of a pension plan's net financial liabilities. In a spot market setting an employer's net liability corresponds simply to the accrued value of vested pension benefits. Additional pension liabilities projected to arise from future employment, in such a setting, are matched dollar for dollar by future projected revenues associated with the worker's continued employment. The excess of projected over accrued liabilities should not, therefore, affect a firm's valuation and suggests no case for estimating and disclosing projected pension liabilities. Under a long-term contract arrangement, on the other hand, revenue from continued employment need not match the accrual of future pension liabilities, plus the payment of tenure wages, and the disclosure of projected rather than accrued liabilities is potentially more relevant for firm financial valuation.

A third question is the effect of pensions on labor mobility and hiring practices. In a spot market environment the particular and quite peculiar rates of pension benefit accrual with age described here would have no consequences for labor mobility, since offsetting increases or reductions in direct wage compensation would leave the worker indifferent between staying on the current job or switching to another job offering an identical amount of total compensation. A spot market would also entail flexibility in wage compensation sufficient to permit hiring equally productive old and young, black and white, male and female workers, despite differences in their accrual of vested pension benefits reflecting age, race, and sex specific mortality probabilities. Long-term contractual agreements, in constrast, may leave less flexibility to accomodate differences in individual circumstances. 
Given knowledge of a worker's current and previous level of earnings, and the benefit and retirement provisions of his pension plan, one could, in principle, directly test the spot market hypothesis by checking whether, in each year, the sum of the increment to a worker's accrued vested pension benefits plus his wage compensation equalled his marginal product. ${ }^{2}$ Unfortunately, a worker's marginal product is unobservable and difficult to estimate. In addition new government data linking pension plan provisions and the earnings histories of participating workers have not yet been released. ${ }^{3}$ These data limitations restrict, but, by no means, preclude inferences about spot versus contractual labor market arrangements. 4

While little is known about the typical profile of marginal productivity by age, it seems safe to assume that this schedule does not exhibit sharp discontinuities. In addition, while there is currently no publicly available means of matching particular earnings histories with particular pension plans, there is considerable information available concerning the typical shape of ageearnings profiles.

This paper calculates the pattern of accrual of vested pension benefits for alternative, but realistic, age-earnings profiles. These accrual profiles are computed for a large sample of plans contained in the Bureau of Labor Statistic's 1979 Level of Benefits Survey (BLS-LOB). This new pension data, based on a survey of 1,469 establishments with 3,386,121 pension participants, provides extremely detailed information concerning pension benefits, vesting, and early retirement formulas, all of which are key inputs to the calculation of pension accruals. 
The sum of the assumed age-earnings profile, measured in constant dollars, and the associated real pension accrual profile equals, under the spot market assumption, the age-marginal productivity profile. Hypothetical agemarginal productivity profiles derived in this manner exhibit rather sharp discontinuities at two critical ages, the age of full vesting, for plans with cliff vesting, and the early retirement age, for plans permitting early retirement on better than actuarially fair terms. For a large fraction of pension plans making reasonable assumptions concerning age-earnings profiles and interest rates, we find discontinuities as large as 50 percent of wage compensation depending on the worker's age at hire. An alternative statement of these findings is that for smoothly shaped age-marginal product schedules, wage compensation must potentially fall or rise by roughly 40 percent of the wage at the age of cliff vesting and other critical ages to satisfy conditions of spot market equilibrium. These figures appear sufficiently large to rule out the hypothesis of spot clearing for a large segment of the U.S. labor market. In addition to the potentially large discontinuities in pension benefit accruals, the pattern of accruals also sheds considerable light on the potential role of pensions in discouraging worker turnover. In many instances even workers who change jobs with no loss in wage compensation and commence employment in a new firm with an idential pension plan lose a large amount in pension benefits.

The accrual patterns also permit inferences about incentives that pensions provide for early retirement. Under our actuarial assumptions we find positive pension accruals on average throughout the work span, i.e., worker 
separation at any time prior to normal retirement typically involves a loss of remuneration in excess of the loss in wage compensation. These findings appear to differ from those of Lazear (1983), who finds that after the age of early retirement, continued work typically involves a loss in pension benefits. Part of the difference in results is due to differences in interest rate and nominal wage growth assumptions. In addition, we do not consider in this paper benefits for all plans covered by the LOB survey. In particular, all plans used in this analysis base benefits on wages.

As Lazear's (1983) insightful study points out, the present expected value of accrued pension benefits represents a form of severance pay for workers who choose to separate from the firm. Such severance pay would naturally arise in contractual settings in which workers are paid (in wages) less than their marginal products. The severance pay may be thought of as the return of the worker's bond which he puts up to guarantee the quality and quantity of his work effort. As the worker ages the value of this "severance pay" rises according to our findings. In a contractual setting the implication of our finding of positive average pension accrual at all ages prior to normal retirement is that real wages represent a lower bound for the average marginal product of workers covered by our sample of plans. It is important to emphasize, however, that we find large deviations from the average, with large negative accruals after the age of early retirement under the provisions of many plans.

Finally, an additional implication of our findings is that compensating differential studies of the tradeoff between wages and pension benefits, if they are to be meaningful, cannot be based on cross-section evidence at a point in 
time. To understand the relationship between compensation in the form of wages versus pension benefits, one must consider the receipt of both over a long period of employment.

The next section describes procedures used to calculate pension benefit accrual and presents illustrative accrual rates for a standard earnings-based defined benefit plan, but one that is not integrated with social security. This plan is also used to demonstrate the sensitivity of accrual rates to assumptions about wage inflation and interest rates. Section II presents evidence concerning age-earnings profiles, suggesting, in particular, that for fully employed workers between ages 55 and 65 who remain in a given firm, nominal earnings grow on average at rates commensurate with, if not greater than, inflation. The assumption of positive nominal wage growth after age 55 is crucial for generating positive pension benefit accrual between 55 and 65 . Section III describes the BLS-LOB data set in more detail and examines the heterogeneity of accrual profiles for our sample of 1183 plans. 5 We conclude section III by drawing inferences from these data concerning the weight of evidence in favor of contractual as opposed to spot labor markets. Section IV summarizes principal findings and suggests areas for future research. 
I. Pension Benefit Accrual Formulae and Illustrative Graphs of Accrual Profiles

A. Accrual Formulae

To begin, consider the benefit accrual profiles shown in Figure 1 . The nominal wage growth incorporated in the top profile assumes moderate life cycle growth in real wages plus a 6 percent rate of inflation. A 3 percent real interest rate (or 9 percent nominal rate) is also assumed. The lower graphs are based on 6 and 9 percent real (12 and 15 percent nominal) interest rates respectively. In the paragraphs below we describe features of pension benefit formulae that produce the unusual shapes of these profiles.

Vested pension benefit accrual at age $a, I(a)$, equals the difference between pension wealth at age $a+1, \operatorname{Pw}(a+1)$, and pension wealth at age a, $\mathrm{Pw}(\mathrm{a})$, accumlated to age $\mathrm{a}+1$ at the nominal interest rate $r$, i.e.:

$$
I(a)=P_{W}(a+1)-P_{W}(a)(1+r)
$$

Pension wealth at age $a$ is defined as the expected value of vested pension benefits discounted to age a. Intuitively, $P w(a)$ can be thought of as the worker's pension bank account. If $I(a)$ equals zero, the worker continuing employment with the plan sponsor at age a has exactly the same pension wealth at age a +1 as an identically situated worker who terminates employment at age a. Pension accrual is thus the increment to pension wealth in excess of the return on the previously accumulated pension bank account.

If the labor market exhibits spot market equilibrium, I(a) plus the worker's non-pension compensation at age a, $W(a)$, equals the worker's mirginal product at age a, $M(a)$ : 


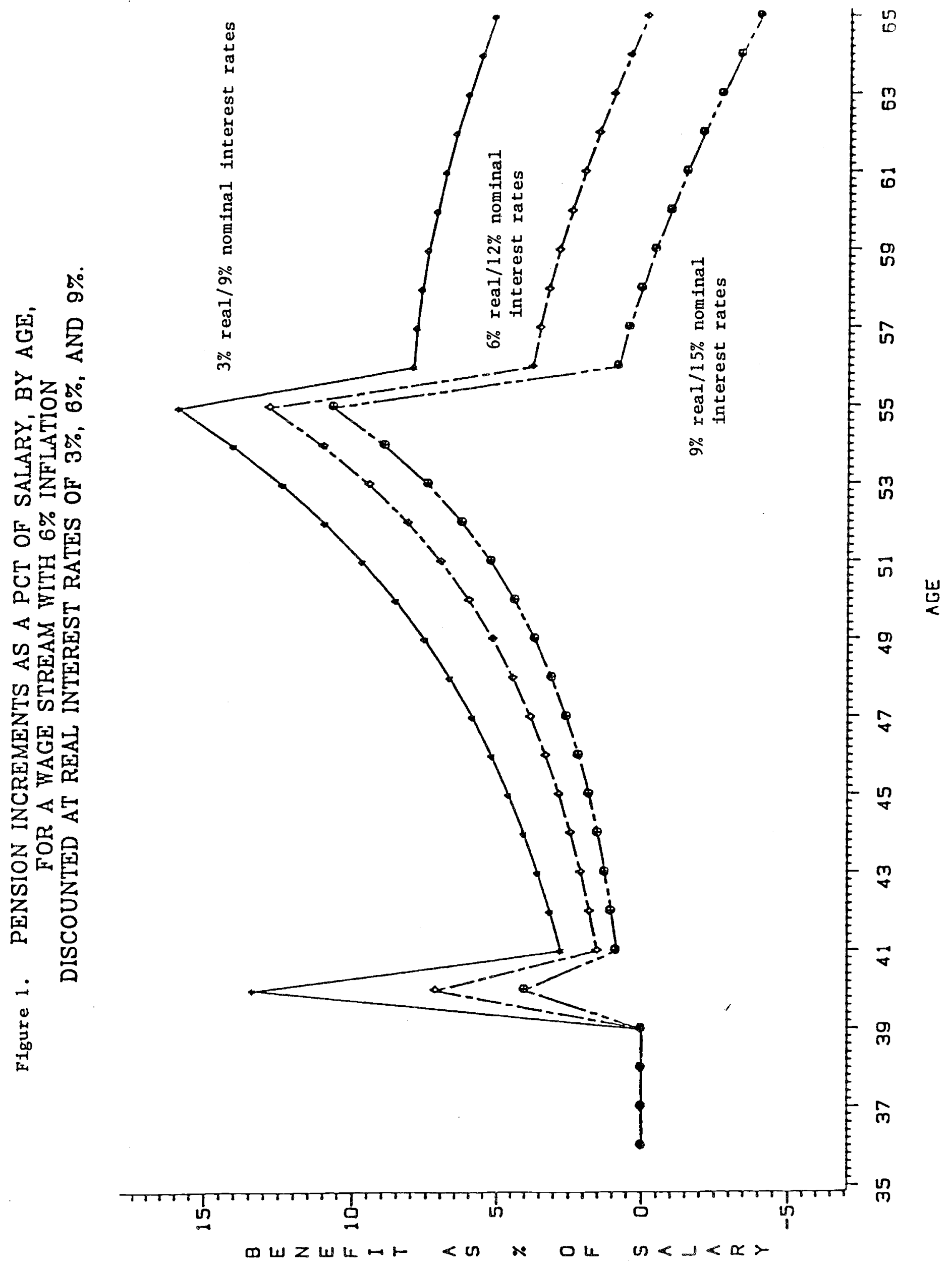




$$
M(a)=W(a)+I(a)
$$

Obviously, if $W(a)$ is a smooth function of age, and $I(a)$ exhibits sharp discontinuities, $M(a)$ mast exhibit sharp discontinuities at these same ages to satisfy (2)

The source of discontinuities in age accrual profiles is clarified by considering a simple earnings-related defined benefit plan with "cliff vesting" at 10 years of service. Vested accrued benefits are clearly zero prior to the age at which the worker has ten years of credited service in the plan. Let $R(a, t)$ denote the ratio of $I(a)$ to $W(a)$ for a worker age a with $t$ years of tenure. Then $\mathrm{R}(a, t)$ is zero for $t<9$, If a person age a with 9 years of service works an additional year, the ratio of the increment to the wage $W(a)$ is

$$
R(a, 9)=\frac{B(a, t) A(55)(1+d)^{-10}(1+r)^{-(55-(a+1))}}{W(a)}
$$

In $(3), B(a, t)$ is the retirement benefit available to the worker who terminates employment with the plan sponsor at age a after $t$ years of service, but who delays receipt of pension benefits until the plan's normal retirement age. The normal and early retirement ages assumed for this stylized plan are 65 and 55 respectively. Terminating workers are, however, eligible for early retirement benefits. Our hypothetical plan reduces benefits by d percent for each year that early retirement preceeds normal retirement. The benefit reduction rate, $d$, could be greater than, equal to, or less than the actuarial fair rate. Today most plans of fering early retirement appear to stipulate smaller than actuarially fair reduction rates; consequently, the formulae presented here assume that workers always gain by receiving their vested accrued benefits at 
the earliest possible date.

The function $A(55)$ is the actuarial discount factor that transforms benefit flows initiating at age 55 into expected stocks of pension wealth at age 55. Expectations here are taken with respect to longevity. Thus $A(55)$ is the annuity value of a dollar's worth of pension benefits to be received each year until death, beginning at age 55. For simplicity assume that the probability of dying prior to age 55 is zero. Hence the present value at age a of $A(55)$ is $A(a)=A(55)(1+r)^{-(55-a)}$ for $a \leq 55$. If pension benefits are determined as a constant $\lambda$ times the product of final year's earnings and service, and there is no offset for receipt of social security benefits, $B(a, t)$ is simply:

$$
B(a, t)=\lambda w(a) t, \quad \text { and }
$$

$$
R(a, 9)=\lambda(1+d)^{-10}(1+r)^{-(55-(a+1))} A(55) 10 \cdot \frac{W(a+1)}{W(a)} \text {. }
$$

$R(a, t)$, for $t$ increasing pari-passus with age, is zero prior to $t$ equals 9 and Jumps at $t$ equals 9 to the value given in (5). Cliff vesting thus produces spikes in the accrual profile such as that in Figure 1 at 10 years of service. Between the age at cliff vesting and age 55, pension wealth $\mathrm{Pw}(\mathrm{a})$ is given by:

$$
P W(a)=\lambda W(a)(1+d)^{-10}(1+r)^{-(55-a)} A(55) t,
$$

and the increment to pension wealth $I(a)$ divided by the wage $W(a)$ is given by

$$
R(a, t)=\lambda(1+d)^{-10}(1+r)^{-(55-(a+1))} A(55) t\left[\frac{W(a+1)}{W(a)} \frac{t+1}{t}-1\right] \text {. }
$$


Equations (7) and (5) suggest a drop in $R(a, t)$ as a increases to $a+1$.concurrent with an increase in $t$ from 9 to 10. Equation ( 7 ) will be positive if the term in brackets exceeds zero. This will be the case if the percent increase in the wage plus the percent increase in years employed $(1 / t)$ is greater than zero. Assuming the term in brackets is positive and is roughly constant, $R(a, t)$ will increase exponentially due to the exponential decline in the discount factor, $(1+r)^{-(55-(a+1))}$, as a approaches 55 . If the value of $d$ is considerably less than actuarially fair, a discontinuity in $R(a, t)$ occurs at the early retirement age, 55 . At ages 55 and 56 we have :

$$
\begin{aligned}
& P_{W}(55)=\lambda W(55)(1+d)^{-10} A(55) t, \text { and } \\
& P w(56)=\lambda W(56)(1+d)^{-9} A(56)(t+1) .
\end{aligned}
$$

Hence,

$$
R(55, t)=\lambda(1+d)^{-10}(1+r) A(55) t\left[\frac{W(56)}{W(55)}\left(\frac{t+1}{t}\right) \frac{A(56)}{A(55)} \frac{(1+d)}{(1+r)}-1\right]
$$

Assuming wage growth at 54 is close to that at 55 and $A(56)$ approximately equals $A(55)$, then $R(55, t)$ primarily differs from $R(54, t-1)$ because the first terms in the bracket in $(7)$ is now multiplied by $(1+d)$ while the second term, -1 , is multiplied by $(1+r)$. Since $r$ exceeds $d$ by assumption, $R(55, t)$ can easily be less than $R(54, t-1)$. Indeed, this change in the functional form of $R(a, t)$ can produce sharp drops in accrual rates at the early retirement age 
for a host of pension plans and a range of realistic economic assumptions. Figure 1 illustrates such discontinuities.

It is important to realize that the early retirement reduction, lower wages, and one less year of tenure yield lower benefits at 55 than at 56 . The early retirement reduction reduces benefits at the rate d. But if benefits were taken at 55 they could accrue interest at the rate $r$. Thus by foregoing the early retirement option of receiving benefits at 55 , a cost is incurred that depends on the difference $r-d$. If this loss is not offset by the increase due to wage growth and 1 year of additional tenure, there will be a drop in the benefit accrual rate between 55 and 56.

The same considerations pertain to benefit increments between 56 and 65. Recall that we have assumed a less than fair early retirement reduction so that benefits accrued before 55 are valued assuming receipt of benefits at the age that yields maximum pension wealth. The optimum time to receive benefits accrued between 55 and 56 is 56 , between 56 and 57 is 57 , and so forth. But to gain benefits from working another year, it is necessary to forego the option of immediately taking accrued benefits at an advantageous reduction rate. Between ages 56 and $65, R(a, t)$ equals :

(11) $R(a, t)=\lambda(1+d)^{-(65-a)}(1+r) A(a) t\left[\frac{W(a+1)}{W(a)} \frac{(t+1)}{t} \frac{A(a+1)}{A(a)} \frac{(1+d)}{(1+r)}-1\right]$.

In contrast to the $R(a, t)$ formula in ( $T$ ) applying to the period between cliff vesting and early retirement, (11) indicates that the actuarial reduction factor--rather than the interest rate $r$--imparts an upward tilt in the $R(a, t)$ 
profile between early and normal retirement, as long as the term in brackets is positive. In (11) as in (7) and (10) the accrual rate, $R(a, t)$ is an increasing function of the rate of nominal wage growth. Larger nominal interest rates reduce accrual rates at all ages, with a negative interaction with age prior to early retirement.

Finally, while equation ( 7 ) is unlikely to be negative, wide differences between wage growth and the interest rate $r$ can yield negative increments in pension wealth after the early retirement age. To a first approximation, the bracketed term in equation (11) will be positive if $\Delta \bar{W} / \bar{W}+1 / t>r-d$ where $\Delta \mathrm{W} / \mathrm{W}$ is the percent increase in wages and $1 / \mathrm{t}$ the percent increase in tenure. It is easy to see, however, that low wage growth and high interest rates will yield negative increments. Thus actuarial increments after the early retirement age are very sensitive to assumed values for wage growth and the interest rate. While the preceeding formulae are suggestive of the general shape of accrual rate profiles, there are few earnings-based plans with features as simple as the one considered here. In addition to more complicated rules for plan participation and vesting that often involve age as well as service requirements, there are a variety of methods of computing earnings bases, including career averages, and averages of earnings, possibly highest earnings, over a specified period or number of years. Reduction rates for early retirement are often a specified function of age, if not length of service. Some plans allow no further accrual after a given number of years of service. Roughly thirty percent of defined benefit participants belong to plans that are integrated with social security. There are two, not necessarily independent, important forms of "integration." One involves a "step rate" benefit formula that uses a different value for the percentage of the product of earnings times 
service for levels of earnings below and levels above specified values. The second is referred to as an "offset" formula which reduces pension benefits by some fraction of the participant's basic social security benefit. Many of the offset plans set ceilings on the extent of the offset. A minority of plans, in particular, those with social security offset formulae, provide supplemental benefits for early retirees prior to their receipt of social security benefits. The supplemental benefit formulae can also be fairly involved, incorporating both the participant's age and service in the calculation. There are also plans that use one benefit formula to compute early retirement benefits and a different formula to determine normal retirement benefits. In addition to these earnings-related plans, a significant number of plans covering over forty percent of defined benefit participants calculate benefits independent of the participant's earnings history. 6 These formulae can also be quite complex. There are other plans that are earnings related, but provide differing flat benefit amounts based on the participant's earnings bracket. Finally there are plans that specify minimum and maximum benefit levels.

Each of these additional features can significantly alter the profile of accrual rates by age, especially the extent of discontinuities in the profile. Our analysis in section IV of pension plans in the BLS-LOB sample takes account of a great number of these complexities. Two important exceptions in the current paper are plans with non-earnings related benefit formulae and plans with supplemental benefit formulae. These plans will be considered in future research. 
The assumption of constant nominal interest rates implies a quite different pattern of pension accrual than would occur with variable interest rates. Changes in long term nominal interest rates produce capital gains and losses on previously accumulated pension wealth that do not directly affect pension accrual. However, as indicated in equations $(5),(7),(10)$ and $(11)$, accrual rates are also a direct function of the currently prevailing long-term interest rates. A time path of varying interest rates around a constant mean would produce a much more discontinuous age-pension accrual profile than those of Figure 1 and other diagrams in this paper.

\section{B. Illustrative Graphs of Accrual Profiles}

Figure 2 depicts three accrual rate profiles for a worker who begins participating at age 30 in a defined benefit plan similar to that described above. The plan calculates normal retirement benefits as 1 percent of average earnings over the last 5 years of service times years of service. Benefits are reduced by 3 percent for each year that early retirement preceeds normal retirement. Cliff vesting occurs after ten years. The early and normal retirement ages are 55 and 65 respectively.

Nominal wage growth is determined by two factors, a cross-sectional profile of "merit" increases by age and an assumed economy-wide rate of wage inflation. The merit profile involves approximately a 50 percent growth in real wages between ages 30 and 50 and very little growth from 50 to 65 . The rate of wage inflation incorporates both across-the-board increases in labor 
0

范

5

E

A. 5

4

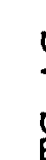

.

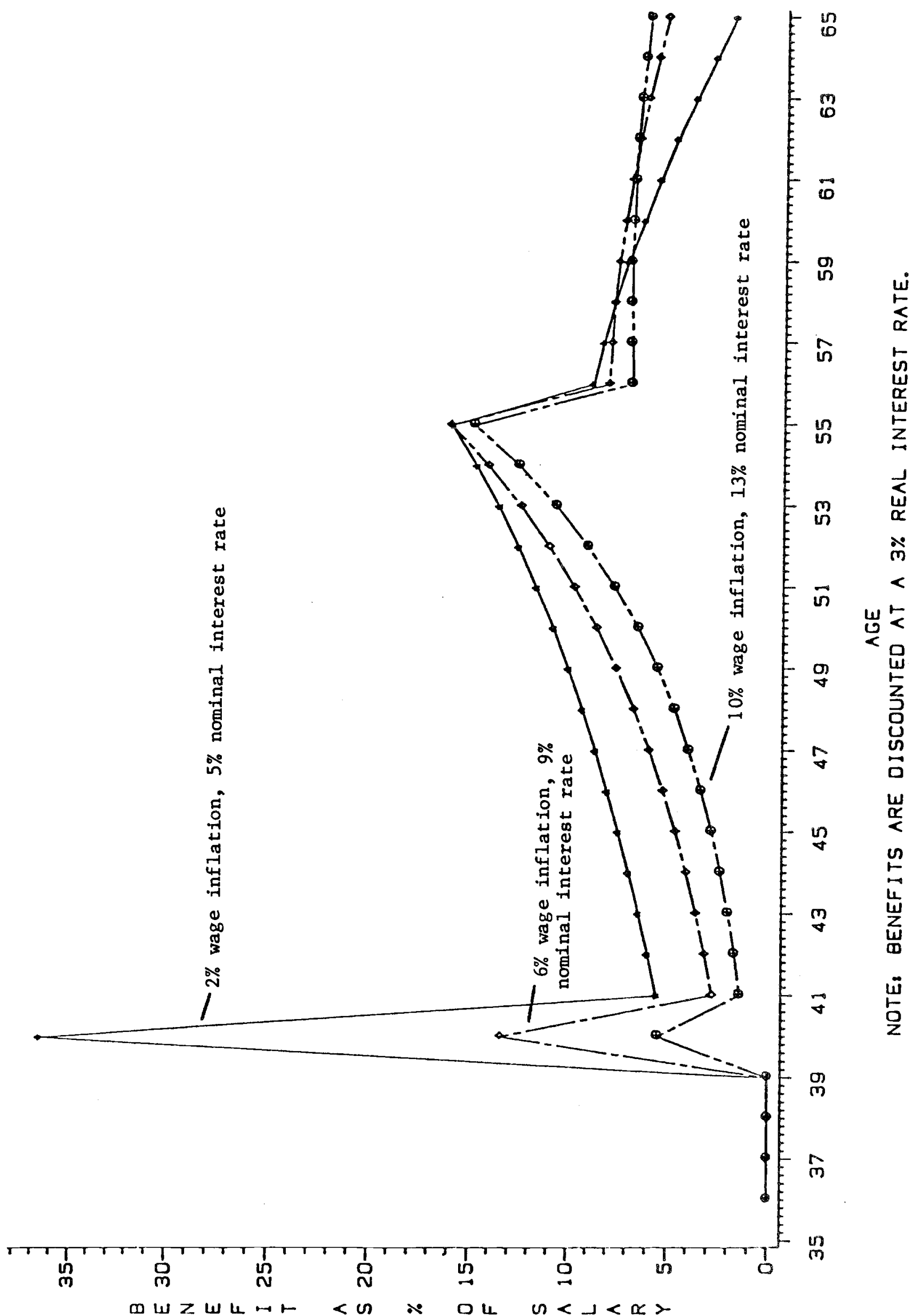


productivity and the price level. The three profiles in Figure 2 differ both in their assumed rate of wage inflation and nominal interest rates. The 2 percent wage inflation profile discounts pension benefits at a 5 percent nominal rate, while the 6 and 10 percent wage inflation profiles use 9 and 13 percent nominal interest rates respectively.

These assumptions about wage growth and nominal interest rates produce "vesting spikes" ranging from 5 to 37 percent of wages at age 40. The intermediate wage and interest rate assumption produces a 14 percent spike at cliff vesting. All three profiles indicate reductions in the accrual rate of about 8 percentage points at age 56. In order to reconcile these profiles with the dictates of spot market equilibrium one mast believe that marginal products rise abruptly by an additional 5 to 37 percent exactly at age 40 and then fall by an additional 3 to 31 percent exactly at age 41 . In addition, an abrupt decline in the worker's marginal product of close to 8 percentage points exactly at age 56 that occurs neither prior to nor after age 56 is required for the theory of spot equilibrium.

One response to these profiles is that straight wage compensation, rather than increasing smoothly through time, could adjust to meet the spot market. Figure 3 suggests the implausibility of this view. Here accrual rate profiles for workers joining the pension plan at ages 30,40 , and 50 are presented based on the intermediate wage and interest rate assumptions of Figure 2 . The vesting spikes for the three profiles are 14, 36 and 66 percent of the corresponding wage at ages 40,50 , and 60 . While vesting at these latter ages 

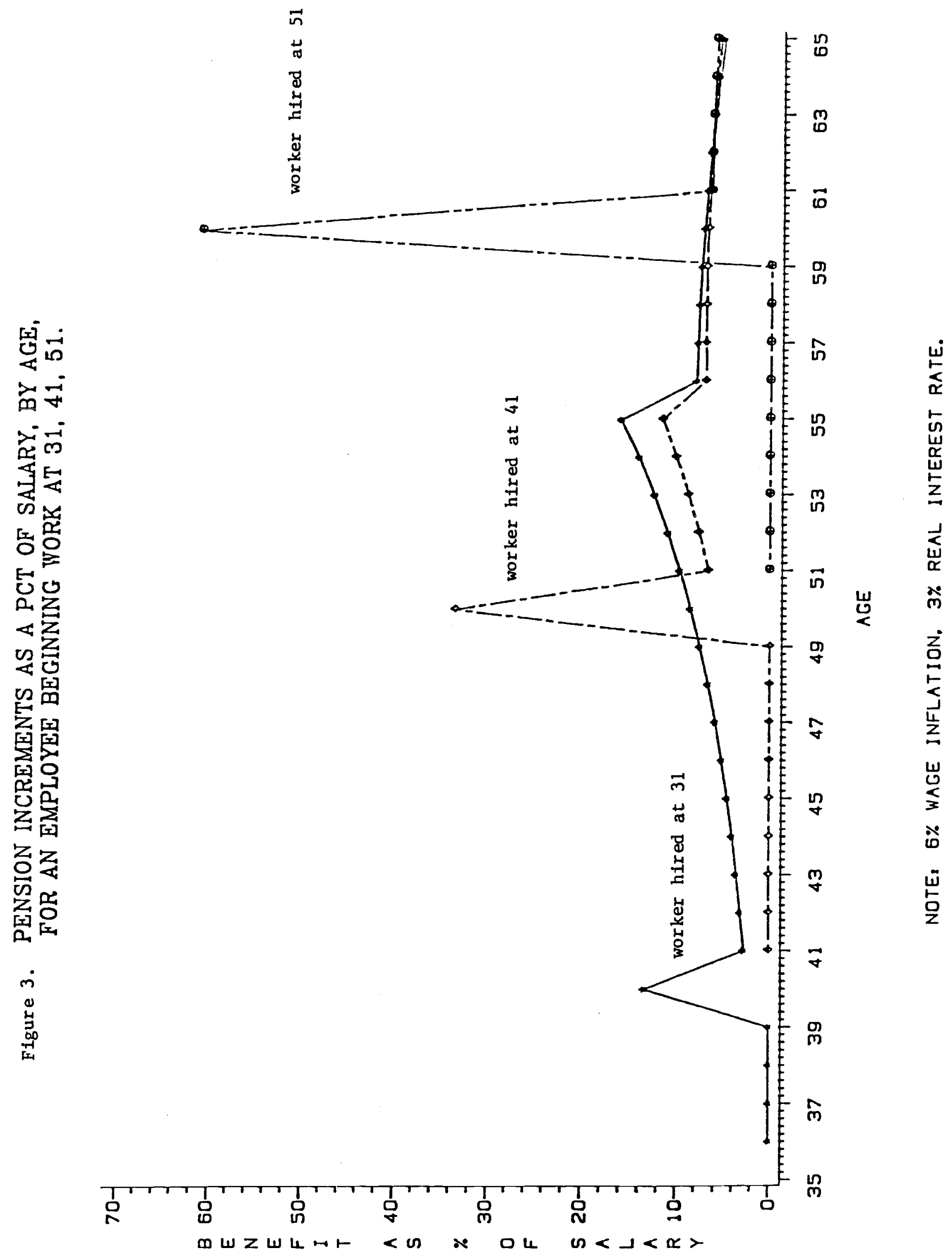
is much less common than prior to age 40, Kotlikoff and Smith (1983) report that over a quarter of current defined benefit pension recipients retired with 20 or fewer years of service. 7

Figure 3 is constructed under the assumption that the workers of the same age receive identical wage compensation. Thus the diagram indicates the potential loss in accrued pension benefits for workers who switch jobs, but receive the same wage compensation in the new job and are covered by the same pension plan. We present below a similar diagram, based on a plan like our base plan, but without the early retirement option. In this case, the loss is substantially greater.

Figure 4 highlights the importance of the early retirement benefit reduction formula for pension accrual. The profile labeled "early retirement option" repeats the accrual profile from figures 2 and 3 based on intermediate economic assumptions. The "retirement at 65 only" profile indicates the pattern of accrual rates for the same plan, but excludes the early retirement option. This profile could also be labelled "actuarially fair accrual rates" since, by definition, an actuarially fair early retirement reduction formula produces an accrual profile that is independent of the age at which benefits are first received.

To the extent that retirement benefits provide an incentive to continue working, the incentive is much greater without the early retirement option than with it. It is important to realize that the difference is only a matter of the pattern of accruals; for workers who retire at normal retirement, the total accumulation of accrued benefits is independent of whether the plan does or does not have an early retirement option. 

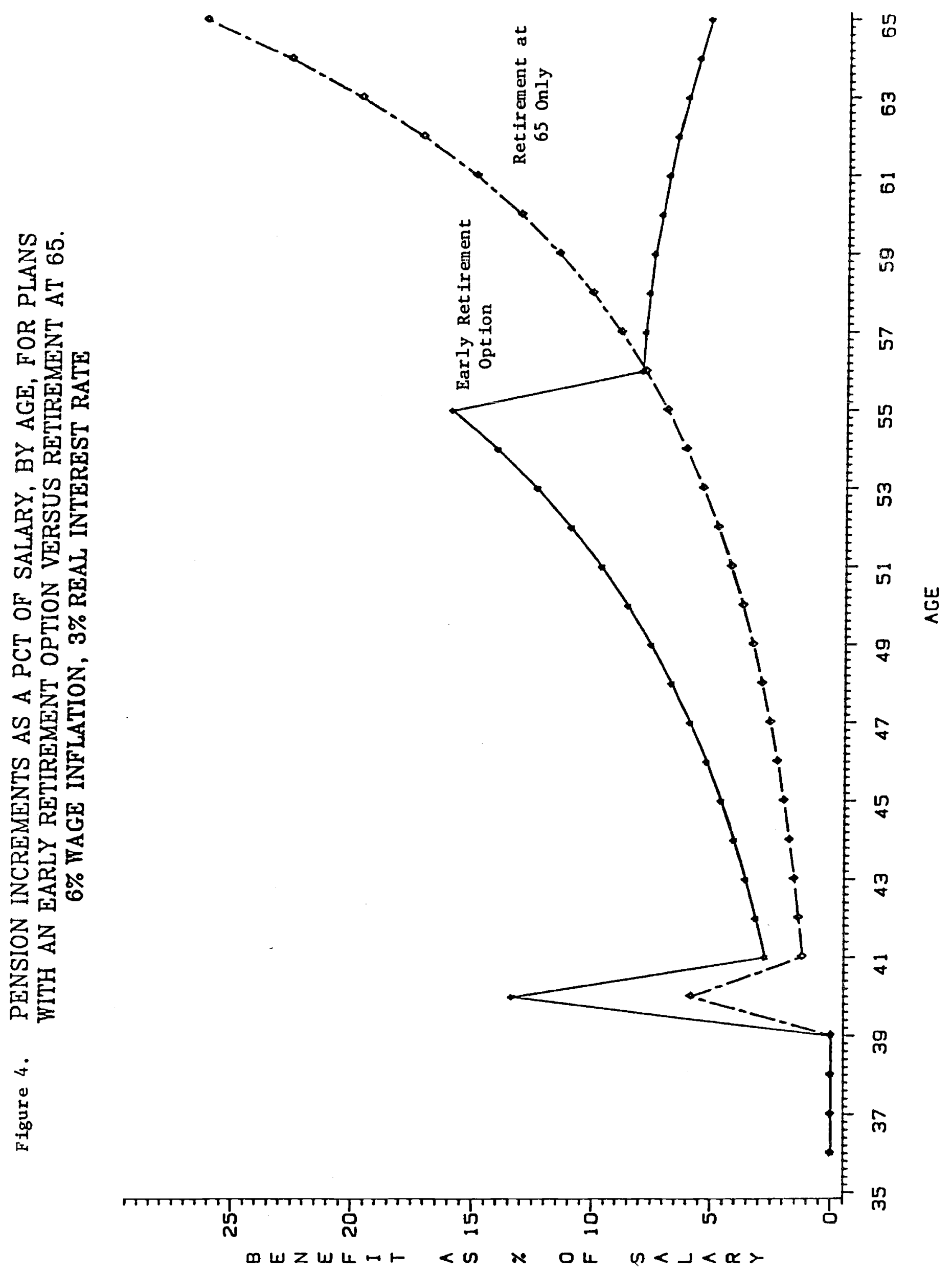
In contrast to the "early retirement option," the actuarially fair "retirement at 65 only" profile exhibits a 6 percent rather than a 14 percent value for $R(a, 10)$ at cliff vesting. In addition there is no discontinuity at age 55 in the latter profile. While these features of the actuarially fair profile are less troubling for the spot market hypothesis, the very rapid rate of benefit accrual between 55 and 65 presents other difficulties for this view of the labor market. The merit schedule built into the nominal wage profile implies a quite limited growth in real wages of workers after age 55 . If anything, this schedule appears to provide for too much growth in real wages after 50 . As described in the next section, cross-sectional profiles of earnings by age decline slightly after age 50 for virtually all classification of workers by occupation and major industry. Since a three percent growth in real wages due to econony-wide productivity growth is above historic averages, one might reasonably infer that real wage growth after age 55 is below three percent. The actuarially fair profile of figure 4, however, entails increases in total real pension remuneration of almost twenty percent of real wages between ages 55 and 65. Needless to say, it is difficult to accept the spot market implication that, in addition to productivity-induced real wage growth, workers at age 65 are twenty percent more productive than they are at age 55. Thus the plan examined in Figure 4 indicates that the difficulty in reconciling pension accrual rates with a spot market is not simply the result of early retirement benefit provisions.

Figure 5 and Figure 1 above demonstrate the sensitivity of the accrual profiles to assumptions about nominal wage growth and nominal interest rates. 
Figure 5 repeats Figure 4 under the assumption of a 10 percent interest rate, but no growth in wages by age. For the profile with the early retirement option accrual rates after age 55 are substantially negative, approaching -15 percent of salary at age 65. With no early retirement option, on the other hand, accrual rates are always positive. The bottom profile in Figure 1 incorporates 6 percent nominal wage growth, but a 15 percent nominal interest rate. The intermediate profile in Figure 1 is based on 6 percent wage growth and a 12 percent nominal interest rate. It yields increments at 65 that are approximately zero. These figures indicate that a considerable gap between nominal interest rates and wage growth rates is needed to produce negative accrual rates.

Finally, we illustrate in Figure 6 the cost of job change with no early retirement option. It should be compared with Figure 3. The plans represented in the two diagrams are the same except that in Figure 6 the early retirement reduction schedule is assumed to be actuarially fair (or, that there is no early retirement option). Again, the top line of this graph shows the accrual rate under our plan for a person who starts work at age 30 (with 6 percent wage inflation and a 3 percent real interest rate). A person with one job change would accumulate benefits up to age 41 according to the top curve, but then would accumulate benefits according to the curve labelled "age 41." Note that no benefits would be accumulated for the first ten years. The difference in accumulated pension benefits at age 65 reflects both the difference in the areas under the two accrual paths and the interest rate used in accumulation of these flows. This difference could be very substantial, and depends, of course, both on when job changes occur and how frequently they occur. It is important to 


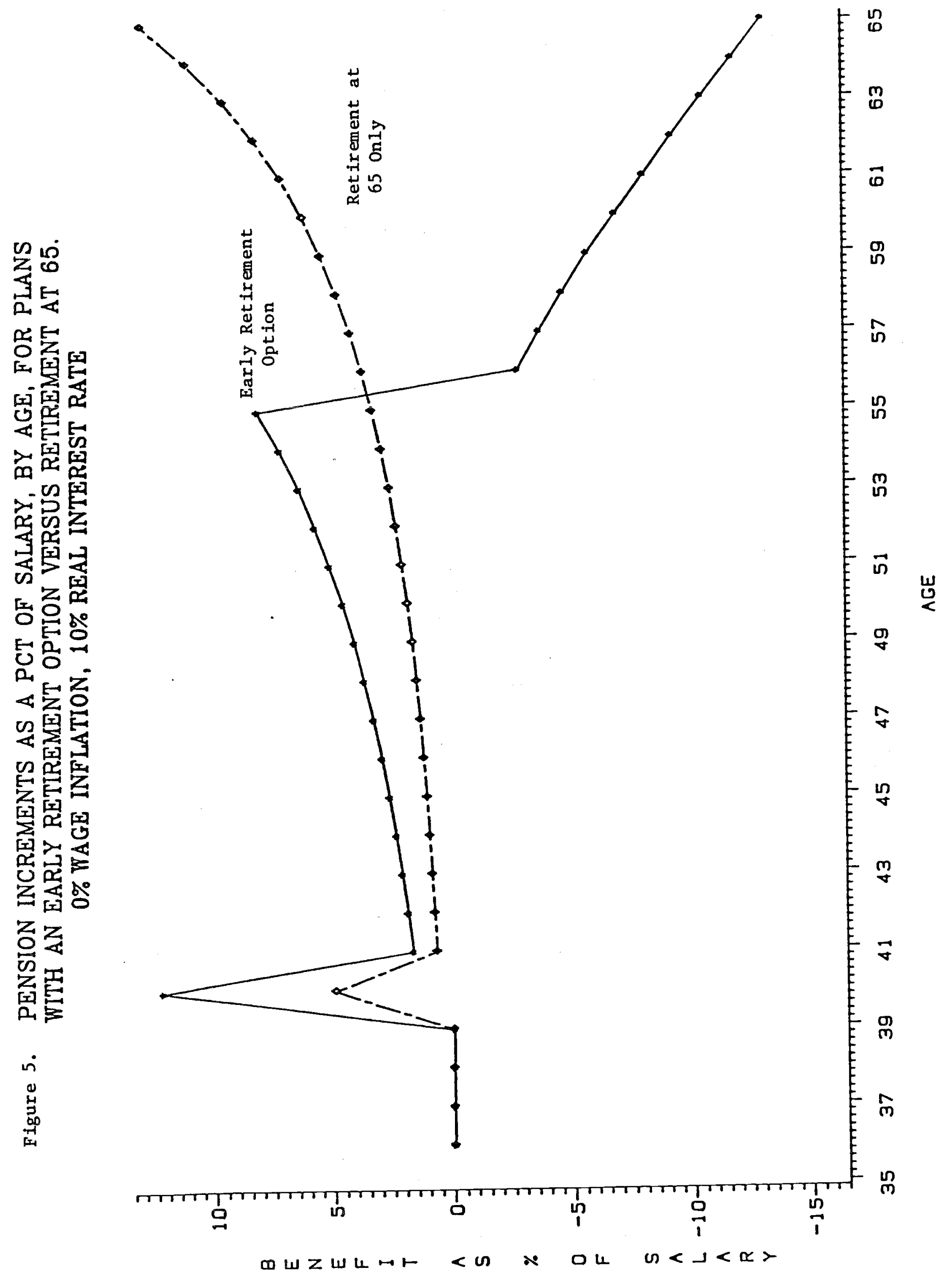



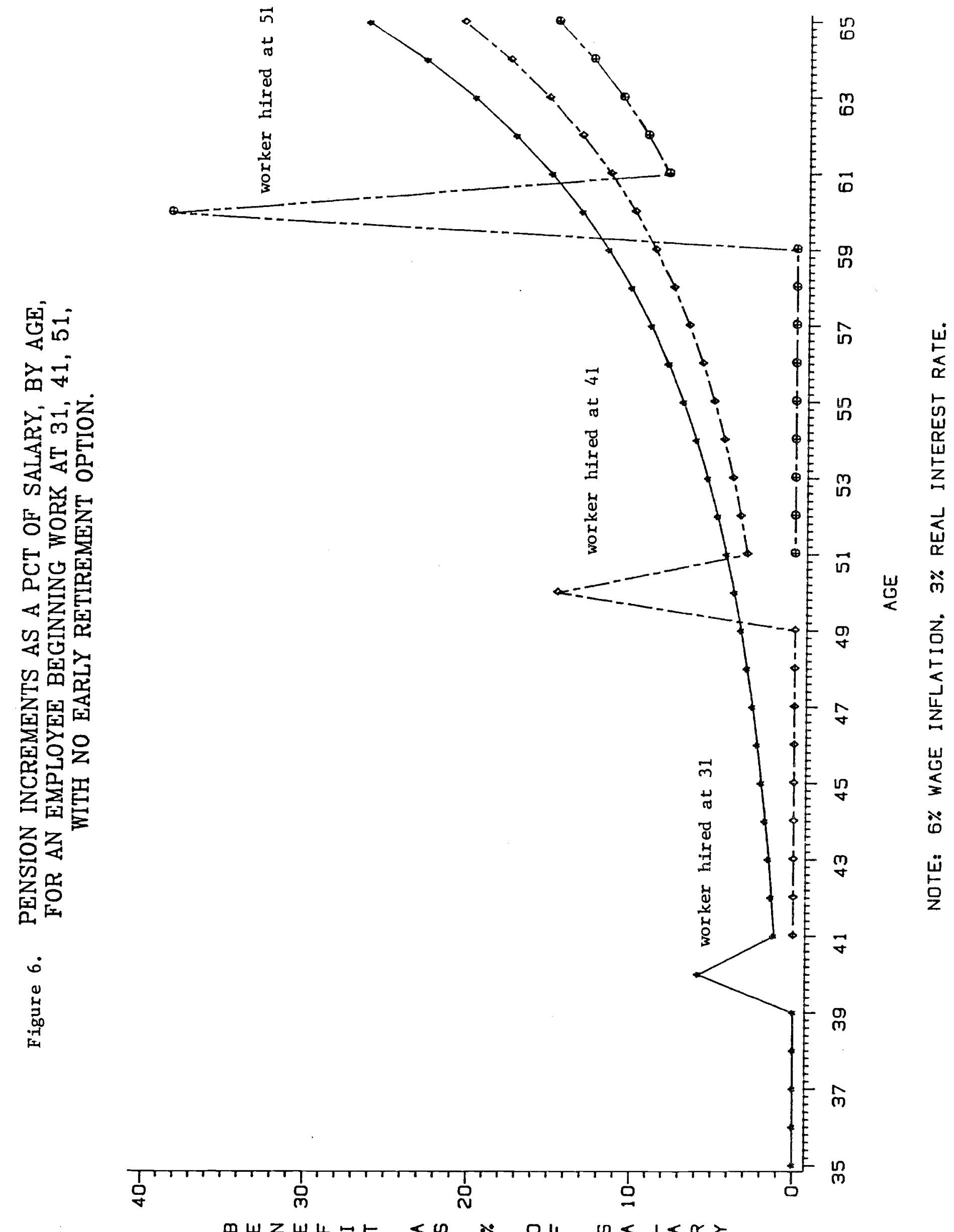
note that the loss in accrued benefits from job change in this example is not due solely to vesting; in figure 6 accrual, in years after vesting occurs, is larger for a worker remaining on the same job for 35 years than for a worker who changes jobs (literally pension plans). This lower accrual beyond vesting for later plan entrants results from the interaction of tenure and wage growth in earnings based defined benefit pension formulae. To see the nature of this interaction consider a plan with immediate vesting that pays 2 percent of final year's salary times years of service. For a worker experiencing positive wage growth who is employed for say 30 years and retires at 60 the pension benefit is 2 percent of the age 60 salary times 30 . If this same worker experiencing the same wage growth were to change jobs each year joining an identical plan his benefit would equal 2 percent times the sum of the 30 annual salaries. Assuming positive wage growth, the pension benefit of the former worker which is based on the age 60 salary will exceed that of the latter worker whose benefit is primarily based on the lower earnings received in earlier years of his career. 


\section{Wage Rate Profiles}

To calculate average pension benefit increments by industry-occupation group, for a given length of employment, we need estimates of age-wage profiles for each group. It is particularly important that assumptions about the wage profiles of older workers be as realistic as possible. Without lengthy longitudinal records on individuals, we have no completely satisfactory way of estimating age-wage profiles. The Retirement History Survey (RHS), however, does provide some longitudinal data for older workers. ${ }^{8}$ We first discuss evidence from these data, and then present estimated age-wage profiles based on the Current Population Survey (CPS) data. For older workers the two sources of data seem to provide roughly consistent evidence.

The age-wage profiles appropriate for determining pension accrual are clearly those pertaining to workers staying in the same firm, thus tenure as well as age should be included in the analysis of earnings by age. Our accrual profiles also assume full-time employment. Hence, wage rates per unit of time is the appropriate earnings concept for our purposes. While conventionally computed age-earnings profiles sometimes show a downward trend for older workers, this appears due, in part, to a reduction in hours worked, and, in part, to the mix of full time and part-time workers in the sample.

\section{A. Evidence From the Retirement History Survey}

The RHS data is based on a sample of persons who were first surveyed in 1969 when they were between 58 and 63. These respondents were resurveyed every two years until 1979. Table 1 shows the means of hourly wages by age and year 
Table 1. Means of Hourly Wages for Non-Self-Employed Males, by Age and Year

\begin{tabular}{|c|c|c|c|c|c|c|c|}
\hline \multirow[t]{2}{*}{ Age } & \multicolumn{6}{|c|}{ Year } & \multirow[b]{2}{*}{ all years } \\
\hline & 1969 & 1971 & 1973 & 1975 & 1977 & 1979 & \\
\hline 58 & $\begin{array}{l}3.03 \\
(134)\end{array}$ & & & & & & $\begin{array}{l}3.03 \\
(134)\end{array}$ \\
\hline 59 & $\begin{array}{l}3.36 \\
(159)\end{array}$ & & & & & & $\begin{array}{l}3.36 \\
(159)\end{array}$ \\
\hline 60 & $\begin{array}{l}3.14 \\
(155)\end{array}$ & $\begin{array}{l}3.25 \\
(154)\end{array}$ & & & & & $\begin{array}{l}3.19 \\
(309)\end{array}$ \\
\hline 61 & $\begin{array}{l}3.05 \\
(i 30)\end{array}$ & $\begin{array}{l}3.36 \\
(i 49)\end{array}$ & & & & & $\begin{array}{l}3.21 \\
(279)\end{array}$ \\
\hline 62 & $\begin{array}{l}3.12 \\
(i 25)\end{array}$ & $\begin{array}{l}3.50 \\
(134)\end{array}$ & $\begin{array}{l}3.89 \\
(107)\end{array}$ & & & & $\begin{array}{l}3.48 \\
(366)\end{array}$ \\
\hline 63 & $\begin{array}{l}2.91 \\
(93)\end{array}$ & $\begin{array}{l}3.30 \\
(115)\end{array}$ & $\begin{array}{l}4.10 \\
(j 03)\end{array}$ & & & & $\begin{array}{l}3.44 \\
(311)\end{array}$ \\
\hline 64 & & $\begin{array}{l}3.41 \\
(74)\end{array}$ & $\begin{array}{l}3.53 \\
(80)\end{array}$ & $\begin{array}{l}4.03 \\
(61)\end{array}$ & & & $\begin{array}{l}3.63 \\
(215)\end{array}$ \\
\hline 65 & & $\begin{array}{l}3.44 \\
(44)\end{array}$ & $\begin{array}{l}3.15 \\
(34)\end{array}$ & $\begin{array}{l}3.54 \\
(41)\end{array}$ & & & $\begin{array}{l}3.39 \\
\text { (119) }\end{array}$ \\
\hline 66 & & & $\begin{array}{l}3.45 \\
(24)\end{array}$ & $\begin{array}{l}3.59 \\
(24)\end{array}$ & $\begin{array}{l}4.62 \\
(18)\end{array}$ & & $\begin{array}{l}3.82 \\
(66)\end{array}$ \\
\hline 67 & & & $\begin{array}{l}3.24 \\
(21)\end{array}$ & $\begin{array}{l}2.83 \\
(13)\end{array}$ & $\begin{array}{l}3.48 \\
(22)\end{array}$ & & $\begin{array}{l}3.24 \\
(56)\end{array}$ \\
\hline 68 & & & & $\begin{array}{l}3.85 \\
(14)\end{array}$ & $\begin{array}{l}4.34 \\
(14)\end{array}$ & $\begin{array}{r}4.42 \\
(8)\end{array}$ & $\begin{array}{l}4.17 \\
(36)\end{array}$ \\
\hline 69 & & & & $\begin{array}{r}3.60 \\
(6)\end{array}$ & $\begin{array}{r}2.71 \\
(9)\end{array}$ & $\begin{array}{r}3.82 \\
(7)\end{array}$ & $\begin{array}{l}3.30 \\
(22)\end{array}$ \\
\hline 70 & & & & & $\begin{array}{l}3.25 \\
(10)\end{array}$ & $\begin{array}{r}4.45 \\
(7)\end{array}$ & $\begin{array}{l}3.74 \\
(17)\end{array}$ \\
\hline 71 & & & & & $\begin{array}{r}4.25 \\
(7)\end{array}$ & $\begin{array}{r}4.16 \\
(4)\end{array}$ & $\begin{array}{l}4.21 \\
(11)\end{array}$ \\
\hline 72 & & & & & & $\begin{array}{r}3.21 \\
(7)\end{array}$ & $\begin{array}{r}3.21 \\
(7)\end{array}$ \\
\hline 73 & & & & & & $\begin{array}{r}4.42 \\
(2)\end{array}$ & $\begin{array}{r}4.42 \\
(2) \\
\end{array}$ \\
\hline
\end{tabular}

asource: Retirement History Survey. Excludes people who say they are partially or fully retired. The number of observations used to calculate the associated value is recorded in parenthesis. 
for persons who reported an hourly wage rate and who were not partially or fully retired in a given year. For a given calendar year, these data in general show little decline in wage rates at least through age 63 or 64 . The number of observations per cell is fairly small since the cells only include older individuals who are still working. Possibly those whose wage rates would have fallen from one year to the next are less likely to be in the sample. Analogous calculations showing the median of annual salaries of persons who reported weekly, monthly, or annual salaries, are presented in Table 2. Here again, in the cross section, there are relatively constant real salary levels through age 64 among persons who are not retired, although there seems to be some decline on average. The accrual calculations require, however, nominal wage profiles. From both tables 1 and 2 , it is clear that nominal wages of older workers increased rather rapidly over this period. A more precise indication of nominal increases is shown in Table 3 for all persons who reported weekly, monthly, or annual salaries. The entry corresponding to age 58-60 and the year 1969-71 is the median salary increase between 1969 and 1971 over all persons who were 58 in 1969 and who reported salary figures in both 1969 and 1971. The other entries are calculated in an analogous manner. The table shows very substantial nominal increases over this period, on the order of 6 percent per year on average. (The entries pertain to a two year interval.) Considering the average increments by age in the last column, there is some evidence that the increases declined somewhat with age. At least through 1977--after which our sample sizes are very small--it appears that salary increases for these older workers were in general keeping up with price increases. The percent increases in the Consumer Price Index (CPI) for the years 1969 to 1977 were as follows: 
Tabje 2. Medlans of Annual Salary for Non-Selt-Employed Males,

by Age and Year

\begin{tabular}{|c|c|c|c|c|c|c|c|}
\hline \multirow{2}{*}{ Age } & \multicolumn{6}{|c|}{ Year } & \multirow[b]{2}{*}{ all years } \\
\hline & 1969 & 1971 & 1973 & 1975 & 1977 & 1979 & \\
\hline 58 & $\begin{array}{l}7494 \\
(666)\end{array}$ & & & & & & $\begin{array}{l}7494 \\
(666)\end{array}$ \\
\hline 59 & $\begin{array}{l}7280 \\
(733)\end{array}$ & & & & & & $\begin{array}{l}7280 \\
(733)\end{array}$ \\
\hline 60 & $\begin{array}{l}7280 \\
(683)\end{array}$ & $\begin{array}{l}8372 \\
(485)\end{array}$ & & & & & $\begin{array}{c}7800 \\
(1168)\end{array}$ \\
\hline 61 & $\begin{array}{l}7280 \\
(690)\end{array}$ & $\begin{array}{l}8100 \\
(563)\end{array}$ & & & & & $\begin{array}{c}7600 \\
(i 25 \overline{3})\end{array}$ \\
\hline 62 & $\begin{array}{l}7280 \\
(591)\end{array}$ & $\begin{array}{l}8216 \\
(453)\end{array}$ & $\begin{array}{l}9850 \\
(322)\end{array}$ & & & & $\begin{array}{c}8008 \\
(1366)\end{array}$ \\
\hline 63 & $\begin{array}{l}7225 \\
(454)\end{array}$ & $\begin{array}{l}8000 \\
(413)\end{array}$ & $\begin{array}{l}8800 \\
(339)\end{array}$ & & & & $\begin{array}{c}7860 \\
(1206)\end{array}$ \\
\hline 64 & & $\begin{array}{l}8000 \\
(403)\end{array}$ & $\begin{array}{l}9100 \\
(303)\end{array}$ & $\begin{array}{l}10088 \\
(246)\end{array}$ & & & $\begin{array}{l}9000 \\
(952)\end{array}$ \\
\hline 65 & & $\begin{array}{l}7800 \\
(179)\end{array}$ & $\begin{array}{l}8200 \\
(151)\end{array}$ & $\begin{array}{l}9480 \\
(146)\end{array}$ & & & $\begin{array}{l}8320 \\
(476)\end{array}$ \\
\hline 66 & & & $\begin{array}{l}8944 \\
(110)\end{array}$ & $\begin{array}{l}9200 \\
(107)\end{array}$ & $\begin{array}{r}11600 \\
(76)\end{array}$ & & $\begin{array}{l}9663 \\
(293)\end{array}$ \\
\hline 67 & & & $\begin{array}{l}8320 \\
(911)\end{array}$ & $\begin{array}{l}8942 \\
(90)\end{array}$ & $\begin{array}{r}11830 \\
(56)\end{array}$ & & $\begin{array}{l}9048 \\
(237)\end{array}$ \\
\hline 68 & & & & $\begin{array}{l}9284 \\
(70)\end{array}$ & $\begin{array}{l}8541 \\
(48)\end{array}$ & $\begin{array}{l}6600 \\
(18)\end{array}$ & $\begin{array}{l}8998 \\
(136)\end{array}$ \\
\hline 69 & & & & $\begin{array}{l}8913 \\
(54)\end{array}$ & $\begin{array}{r}10089 \\
(42)\end{array}$ & $\begin{array}{r}4225 \\
(8)\end{array}$ & $\begin{array}{l}9360 \\
(104)\end{array}$ \\
\hline 70 & & & & & $\begin{array}{l}7850 \\
(30)\end{array}$ & $\begin{array}{l}3750 \\
(12)\end{array}$ & $\begin{array}{l}6703 \\
(42)\end{array}$ \\
\hline 71 & & & & & $\begin{array}{l}8525 \\
(23)\end{array}$ & $\begin{array}{l}4160 \\
(10)\end{array}$ & $\begin{array}{l}7380 \\
(33)\end{array}$ \\
\hline 72 & & & & & & $\begin{array}{l}3016 \\
(13)\end{array}$ & $\begin{array}{l}3016 \\
(13)\end{array}$ \\
\hline 73 & & & & & & $\begin{array}{r}7800 \\
(9)\end{array}$ & $\begin{array}{r}7800 \\
(9)\end{array}$ \\
\hline
\end{tabular}

'Source: Retirement History Survey. Excludes people who say they are par-

tially or fully retired. The number of observations used to calculate

the assoclated value is recorded in parenthesis. 
Table 3. Medlan Percent Changes In Annual Salary for Non-Self-Employed Males, by Age and Year ${ }^{*}$

\begin{tabular}{|c|c|c|c|c|c|c|}
\hline \multirow{2}{*}{ Age } & \multicolumn{5}{|c|}{ Year } & \multirow[b]{2}{*}{ ad years } \\
\hline & $1969-71$ & $1971-73$ & $1973-75$ & $1975-77$ & $1977-79$ & \\
\hline $58-60$ & $\begin{array}{l}13.0 \\
(423)\end{array}$ & & & & & $\begin{array}{l}13.0 \\
(423)\end{array}$ \\
\hline $59-61$ & $\begin{array}{l}12.5 \\
(486)\end{array}$ & & & & & $\begin{array}{l}12.5 \\
(486)\end{array}$ \\
\hline $60-62$ & $\begin{array}{l}12.5 \\
(393)\end{array}$ & $\begin{array}{l}12.6 \\
(264)\end{array}$ & & & & $\begin{array}{l}12.5 \\
(657)\end{array}$ \\
\hline $61-63$ & $\begin{array}{l}11=7 \\
(354)\end{array}$ & $\begin{array}{l}11=0 \\
(280)\end{array}$ & & & & $\begin{array}{l}11=1 \\
(634)\end{array}$ \\
\hline $62-64$ & $\begin{array}{l}11.3 \\
(346)\end{array}$ & $\begin{array}{l}11.7 \\
(237)\end{array}$ & $\begin{array}{l}13.3 \\
(170)\end{array}$ & & & $\begin{array}{l}11.5 \\
(753)\end{array}$ \\
\hline $63-65$ & $\begin{array}{l}10.4 \\
(148)\end{array}$ & $\begin{array}{l}11.1 \\
(118)\end{array}$ & $\begin{array}{l}11.1 \\
\text { (10i) }\end{array}$ & & & $\begin{array}{l}11.1 \\
(367)\end{array}$ \\
\hline $64-66$ & & $\begin{array}{l}12.9 \\
(86)\end{array}$ & $\begin{array}{l}12.1 \\
(83)\end{array}$ & $\begin{array}{l}10.5 \\
(64)\end{array}$ & & $\begin{array}{l}12.2 \\
(233)\end{array}$ \\
\hline $65-67$ & & $\begin{array}{r}9.5 \\
(58)\end{array}$ & $\begin{array}{l}12.5 \\
(54)\end{array}$ & $\begin{array}{l}11.4 \\
(45)\end{array}$ & & $\begin{array}{l}10.8 \\
(157)\end{array}$ \\
\hline $66-68$ & & & $\begin{array}{l}10.8 \\
(47)\end{array}$ & $\begin{array}{l}12.8 \\
(37)\end{array}$ & $\begin{array}{l}12.9 \\
(10)\end{array}$ & $\begin{array}{l}11.8 \\
(94)\end{array}$ \\
\hline $67-69$ & & & $\begin{array}{r}6.4 \\
(41)\end{array}$ & $\begin{array}{l}10.1 \\
(36)\end{array}$ & $\begin{array}{l}6.2 \\
(3)\end{array}$ & $\begin{array}{l}8.3 \\
(80)\end{array}$ \\
\hline $68-70$ & & & & $\begin{array}{l}10.6 \\
(18)\end{array}$ & $\begin{array}{r}29.8 \\
(3)\end{array}$ & $\begin{array}{l}13.3 \\
(21)\end{array}$ \\
\hline $69-71$ & & & & $\begin{array}{l}12.5 \\
(20)\end{array}$ & $\begin{array}{r}17.5 \\
(2)\end{array}$ & $\begin{array}{c}12.5 \\
(22)\end{array}$ \\
\hline $70-72$ & & & & & $\begin{array}{r}13.1 \\
\text { (2) }\end{array}$ & $\begin{array}{r}13.1 \\
(2)\end{array}$ \\
\hline $71-73$ & & & & & $\begin{array}{r}15.4 \\
\text { (i) }\end{array}$ & $\begin{array}{r}15.4 \\
\text { (i) }\end{array}$ \\
\hline
\end{tabular}

aSource: Retirement History Survey. Excludes people who say they are partlally or fully retlred. The number of observations used to calculate the assoclated value is recorded in parenthesis. 


\begin{tabular}{lr} 
Year & CPI \\
\hline 1969 & 6.1 \\
1970 & 5.5 \\
1971 & 3.4 \\
1972 & 3.4 \\
1973 & 8.8 \\
1974 & 12.2 \\
1975 & 7.0 \\
1976 & 4.8 \\
1977 & 6.8
\end{tabular}

In short, these data suggest substantial nominal wage increases for older workers, roughly consistent, on average, with overall inflation levels.

B. Wage-Tenure Profiles from the Current Population Survey

To estimate age tenure profiles by industry and occupation group, we matched the May 1979 Supplement to the CPS March 1979 CPS. The May Supplement provides tenure data, while the wage data come from the March tape. We were able to obtain the required wage, age, and tenure information for somewhat over 15,000 persons in the 24 industry-occupation groups distinguished in the LOB survey. Relevant cell sample sizes, however, were large enough to obtain "reasonable" estimates for only 16 groups, noted below.

After considerable experimentation with two-way tables showing average salary by age and tenure, we elected simply to obtain least-squares estimates of wage rates using the specification

$$
w=a_{0}+a_{1} A+a_{2} A^{2}+b_{1} T+b_{2} T^{2}+c A T,
$$

where $\mathrm{W}$ is the wage rate, $\mathrm{A}$ is age, and $\mathrm{T}$ is tenure. To estimate wage levels by age for a person who entered a firm at, for example, age 30 we calculated 


$$
\begin{aligned}
\hat{w}=\hat{a}_{0}+\hat{a}_{1} A+\hat{a}_{2} A^{2} & +\hat{b}_{1}(A-30)+\hat{b}_{2}(A-30)^{2} \\
& +\hat{c}(A)(A-30),
\end{aligned}
$$

for values of $A$ between 30 and 65.

The estimated profiles for the total group, and by occupation over all industry groups, are presented in Figure 7. These profiles are empirical counterparts of the "merit" scale used in the illustrative calculations in section I above.

The cross-sectional age earnings profile (13) for all groups combined increases by about 50 percent between age 30 and age 52 when it reaches its maximum. Then it declines by about 10 percent over the next 13 years, or about .8 percent per year on average. Assuming a wage inflation rate of 6 percent therefore, produces a nominal wage rate for older workers increasing at about 5 percent per year. For older workers this path of nominal wage growth seems to be in rough accord with the evidence from the Retirtment History Survey. In addition to the graphs of the cross-section wage profiles, summary indicators of their shapes are provided in Table 4. It shows salary at age 30 , maximum salary, the age of maximum salary, and salary at age 65, together with average percent increases between the end points and the maximum. 


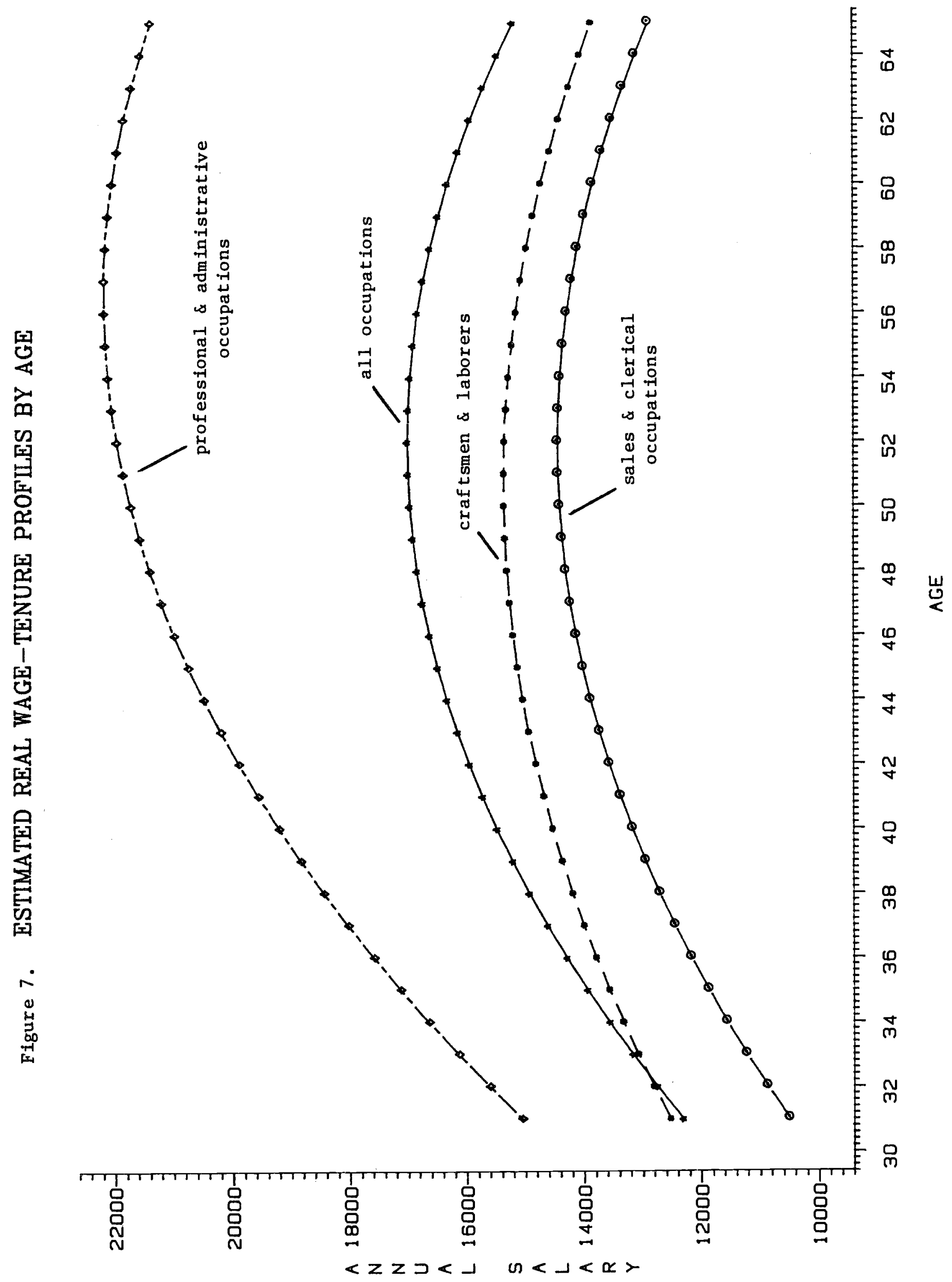


Table 4. Summary Statistics on Wage Proflles by Industry and Occupotion Groupo

\begin{tabular}{|c|c|c|c|c|c|c|}
\hline \multirow{2}{*}{$\begin{array}{l}\text { Industry and } \\
\text { Occupation } \\
\text { AlI }\end{array}$} & \multirow{2}{*}{$\begin{array}{c}\text { Salary at } \\
\text { Age } 30\end{array}$} & \multicolumn{2}{|c|}{$\begin{array}{l}\text { Max Salary } \\
\text { (Age) }\end{array}$} & \multirow{2}{*}{$\begin{array}{c}\text { Salary at } \\
\text { Age } 65 \\
15216\end{array}$} & \multirow{2}{*}{$\begin{array}{l}\text { Average } \\
\text { \& Increase } \\
\text { Age } 30 \text { to } \\
\text { Max Imum } \\
2.0 \\
2.0\end{array}$} & \multirow{2}{*}{$\begin{array}{l}\text { Average } \\
\text { \& Decrease } \\
\text { Maximum to } \\
\text { Age } 65 \\
-0.8\end{array}$} \\
\hline & & 17022 & $(52)$ & & & \\
\hline \multicolumn{7}{|l|}{ All: } \\
\hline $\begin{array}{l}\text { Professlonal and } \\
\text { AdmInIstrative }\end{array}$ & 14470 & 22232 & (57) & 21454 & 2.0 & -0.4 \\
\hline $\begin{array}{l}\text { Sales and } \\
\text { Clerical }\end{array}$ & 10112 & 14446 & $(52)$ & 12890 & 1.9 & -0.8 \\
\hline $\begin{array}{l}\text { Craftsmen and } \\
\text { Laborers }\end{array}$ & 12228 & 15366 & $(51)$ & 13866 & 1.2 & -0.7 \\
\hline MInIng & 18062 & 22676 & $(65)$ & 22676 & 0.7 & -0.0 \\
\hline Construction & 15822 & 18036 & $(45)$ & 13678 & 0.9 & -1.2 \\
\hline \multicolumn{7}{|l|}{ Manufacturing: } \\
\hline $\begin{array}{l}\text { Professlonal and } \\
\text { AdminIstrative }\end{array}$ & 16374 & 24634 & $(55)$ & 23150 & 2.0 & -0.6 \\
\hline $\begin{array}{l}\text { Sales and } \\
\text { Clerical }\end{array}$ & 10670 & 14894 & $(56)$ & 14380 & 1.5 & -0.4 \\
\hline $\begin{array}{l}\text { Craftsmen and } \\
\text { Laborers }\end{array}$ & 10960 & 14822 & (52) & 13294 & 1.6 & -0.8 \\
\hline \multicolumn{7}{|l|}{ Transportation: } \\
\hline $\begin{array}{l}\text { Professlonal and } \\
\text { AdmInistrative }\end{array}$ & 21466 & 25230 & $(65)$ & 25230 & 0.5 & -0.0 \\
\hline $\begin{array}{l}\text { Sales and } \\
\text { Clerlcal }\end{array}$ & 12284 & 16806 & $(48)$ & 13128 & 2.0 & -1.3 \\
\hline $\begin{array}{l}\text { Craftmen and } \\
\text { Laborers }\end{array}$ & 13938 & 17630 & $(64)$ & 17628 & 0.8 & -0.0 \\
\hline Wholesale Trade & 12644 & 18416 & $(48)$ & 12908 & 2.5 & -1.8 \\
\hline \multicolumn{7}{|l|}{ Retall Trade: } \\
\hline $\begin{array}{l}\text { Professlonal and } \\
\text { AdmInIstrative }\end{array}$ & 11268 & 18844 & $(48)$ & 12620 & 3.7 & -1.9 \\
\hline $\begin{array}{l}\text { Sales and } \\
\text { Clerlcal }\end{array}$ & 8528 & 11932 & $(46)$ & 7518 & 2.5 & -1.9 \\
\hline $\begin{array}{l}\text { Craftsmen and } \\
\text { Laborers }\end{array}$ & 10974 & 13538 & $(49)$ & 11816 & 1.2 & -0.8 \\
\hline Flnance & 12072 & 19552 & (59) & 19194 & 2.1 & -0.3 \\
\hline \multicolumn{7}{|l|}{ Services: } \\
\hline $\begin{array}{l}\text { Protessional and } \\
\text { AdmInlstrative }\end{array}$ & 13326 & 19246 & $(54)$ & 17936 & 1.9 & -0.6 \\
\hline $\begin{array}{l}\text { Sales and } \\
\text { Clerlcal }\end{array}$ & 9230 & 10822 & (54) & 10514 & 0.7 & -0.3 \\
\hline $\begin{array}{l}\text { Craftsmen and } \\
\text { Laborers }\end{array}$ & 11220 & 12810 & $(50)$ & 11950 & 0.7 & -0.4 \\
\hline
\end{tabular}


III. Accrual Rates from the BLS Level of Benefits Survey

The BLS-LOB (1979) establishments constitute a subsample of the 1979 National Survey of Professional, Administrative, Technical and Clerical Pay. Based on the file's population weights this subsample covers $17,965,282$ private pension plan participants in the U.S., which is slightly over half of all participants covered by private pensions. The subsample's universe consisted of all firms with over 100 employees with the exception of mining, construction and retail trade establishments where the minimum firm size was 250 employees and service establishments where the minimum firm size was 50 employees. Sampled establishments were requested to report work schedules and information about 11 different types of fringe benefits. This information was provided for each of the three occupational groups. The BLS-LOB (1979) pension benefits tape consists of establishment records for each occupational group that detail features of pension benefit plans covering the particular occupational group in question. Unfortunately firm identifiers are intentionally excluded from the computer record; hence, it is impossible to reconstruct the actual pension characteristics of the initial establishment. The data can, however, be used to estimate industry-wide or occupation-wide values of pension variables.

In this section we examine accrual ratios for 1183 earnings based defined benefit plans. Earnings based plans account for approximately 80 percent of BLS-designated usable plans from the survey and about 65 percent of plans weighted by pension coverage. 9 Each of the 1183 plans stipulates cliff-vesting at 10 years, but the plans have different normal and early retirement ages. Other earnings based plans with different vesting ages have 
accrual profiles similar to those that we shall describe, but for convenience of exposition we have not included them in our analysis here. of the 1183 plans, 508 are integrated with social security under an offset formula.

Table 5 presents weighted average accrual ratios for the 1183 plans by early and normal retirement ages for workers hired at age 31. Our intermediate assumptions of 6 percent nominal wage growth and a 9 percent interest rate are used in conjunction with the industry-occupation-age-earnings profiles discussed in section II. The spike at the age of vesting varies with early retirement and normal retirement ages. It is 24 percent for plans with early and normal retirement at 55. Among the plans with early retirement at 55 the vesting spike declines with the age of normal retirement, with a vesting spike of approximately 12 percent for plans with normal retirement at 60 and a spike of about 7 percent for plans with normal retirement at 65 . For plans with later early and normal retirement ages, the vesting spike is much smaller, ranging from a little over 3 percent to about 5 percent.

A total of 356 plans have the same early and normal retirement ages, i.e., they do not permit early retirement. For example, there are 209 plans with both early and normal retirement at age 55. In this case, the accrual ratio immediately after vesting is about 5 percent and increases to about 15 percent by age 50. Between ages 50 and 55 the accrual ratio increases to almost 27 percent. A similar pattern is observed for the other plans in which the normal and early retirement ages are the same, but the accrual ratios just after vesting are no more than 1 percent in these cases. It may be noted that these plans correspond to our earlier description of plans with no early retirement 
Table 5. Welghted average accrual rates for percent of earnings plans with 10-year clift vesting, by early and normal retirement age."

\begin{tabular}{|c|c|c|c|c|c|c|c|c|}
\hline $\begin{array}{l}\text { Early Ret. } \\
\text { Normal Ret. }\end{array}$ & $\begin{array}{l}55 \\
55 \\
\end{array}$ & $\begin{array}{l}55 \\
60 \\
\end{array}$ & $\begin{array}{l}55 \\
65 \\
\end{array}$ & $\begin{array}{l}60 \\
60 \\
\end{array}$ & $\begin{array}{l}60 \\
65 \\
\end{array}$ & $\begin{array}{l}62 \\
62 \\
\end{array}$ & $\begin{array}{l}62 \\
65 \\
\end{array}$ & $\begin{array}{l}65 \\
65 \\
\end{array}$ \\
\hline No. of Plans & 209 & 152 & 528 & 78 & 53 & 19 & 8 & 50 \\
\hline $\mathrm{Age}$ & & & & & & & & \\
\hline $\begin{array}{l}40 \\
41\end{array}$ & $\begin{array}{l}.239 \\
-046\end{array}$ & $\begin{array}{l}.115 \\
.024\end{array}$ & $\begin{array}{l}.069 \\
.013\end{array}$ & $\frac{.033}{.007}$ & $\begin{array}{l}.047 \\
.010\end{array}$ & $\begin{array}{l}.036 \\
.016\end{array}$ & $\begin{array}{l}.054 \\
.009\end{array}$ & $\frac{.037}{.010}$ \\
\hline 42 & .052 & .027 & .016 & .008 & .010 & .017 & .010 & .011 \\
\hline 43 & .059 & .031 & .108 & .009 & .013 & .020 & .011 & .013 \\
\hline 44 & .067 & .036 & .020 & .011 & .015 & .031 & .013 & .014 \\
\hline 45 & .077 & .041 & .023 & .013 & .017 & .037 & .014 & .016 \\
\hline 46 & .087 & .047 & .026 & .016 & .019 & .042 & .015 & .018 \\
\hline 47 & .099 & .055 & .031 & .027 & .022 & .048 & .017 & .021 \\
\hline 48 & .113 & .063 & .034 & .038 & .025 & .055 & .019 & .024 \\
\hline 49 & .128 & .071 & .040 & .054 & .029 & .062 & .021 & .028 \\
\hline 50 & .145 & .086 & .046 & .063 & .034 & .070 & .023 & .032 \\
\hline 51 & .163 & .085 & .042 & .081 & .040 & .079 & .026 & .033 \\
\hline 52 & .184 & .100 & .062 & .087 & .051 & .081 & .029 & .044 \\
\hline 53 & .209 & .114 & .072 & .101 & .060 & .103 & .032 & .051 \\
\hline 54 & .235 & .130 & .083 & .112 & .068 & .115 & .036 & .056 \\
\hline 55 & .269 & .151 & .097 & .143 & .083 & .130 & .039 & .066 \\
\hline 56 & & .110 & .070 & .163 & .095 & .146 & .036 & .069 \\
\hline 57 & & .116 & .074 & .185 & .107 & .165 & .039 & .078 \\
\hline 58 & & .120 & .079 & .215 & .128 & .188 & .044 & .091 \\
\hline 59 & & .120 & .081 & .232 & .147 & .212 & .049 & .107 \\
\hline 60 & & .215 & .083 & .259 & $: 168$ & .245 & .054 & .121 \\
\hline 61 & & & .074 & & .119 & .223 & .060 & .131 \\
\hline 62 & & & .070 & & .121 & .252 & .066 & .148 \\
\hline 63 & & & .063 & & .122 & & .023 & .167 \\
\hline 64 & & & .060 & & .123 & & .019 & .190 \\
\hline 65 & & & .052 & & .121 & & .012 & .216 \\
\hline
\end{tabular}

a Plans with earjy or normal retirement supplements are excluded. 
provision, as depicted for example in figure 4. We have not calculated accrual ratios after the age of normal retirement, but it appears that in most cases accrual after the normal retirement age is very small and in some cases significantly negative. Hence, there appears to be a very substantial discontinuous drop in the rate of pension accrual after the normal retirement age for a significant fraction of private pension plans. In subsequent work we shall describe in detail the accrual rates of plans after the age of normal retirement.

Plans with early retirement typically exhibit a rather slow increase in accrual ratios after vesting until a few years before the age of early retirement. There is often a sharp drop in the accrual ratio at that age, with either limited increases or gradual declines in accrual ratios thereafter. For example, of the 528 plans with early retirement at 55 and normal retirement at 65 the accrual ratio reaches about 10 percent at age 55 and then drops by about 30 percent to 7 percent at age 56. By age 65 the accrual ratio has fallen to 5 percent. The pattern exhibited by these plans is similar to the one described in figure 4 for a typical plan with a normal retirement provision.

A comparison of plans with and without a social security of fset is presented in table 6 , for plans with early retirement at 55 and normal retirement at 55,62 , or 65 . There are two major differences in these plans: first, the within group weighted average spike at vesting is very substantial for plans without social security offset, ranging from 12 to 26 percent and is very small for plans with a social security offset with the exception of plans with normal retirement at age 55. In this case the average spike at vesting is 
Tobje 6. Welghted average accrual rates for percent of earnings plans

with 10-year clift vesting and early retirement at age 55, by normal retirement age and soclal security offset.

\begin{tabular}{|c|c|c|c|c|c|c|}
\hline \multirow{2}{*}{$\begin{array}{l}\text { Normal Ret. } \\
\text { Offset } \\
\text { No. of Plans }\end{array}$} & \multicolumn{2}{|c|}{55} & \multicolumn{2}{|c|}{62} & \multicolumn{2}{|c|}{65} \\
\hline & $\begin{array}{c}w / 0 \text { of fse } \\
178\end{array}$ & $\begin{array}{c}\text { of fset } \\
31\end{array}$ & $\begin{array}{c}w / 0 \text { offse } \\
124\end{array}$ & $\begin{array}{l}\text { of fset } \\
118\end{array}$ & $\begin{array}{c}w / 0 \text { of fset } \\
261\end{array}$ & $\begin{array}{l}\text { of fset } \\
267\end{array}$ \\
\hline \multicolumn{7}{|l|}{$\mathrm{Age}$} \\
\hline $\begin{array}{l}40 \\
41\end{array}$ & --.258 & $\begin{array}{r}.084 \\
-.014\end{array}$ & $\begin{array}{r}.174 \\
--.- \\
.036\end{array}$ & $\begin{array}{l}.024 \\
---- \\
.009\end{array}$ & $-\frac{.120}{.022}-$ & $\begin{array}{l}.016 \\
-.004\end{array}$ \\
\hline 42 & .057 & .017 & .041 & .012 & .025 & .005 \\
\hline 43 & .064 & .021 & .046 & .015 & .029 & .006 \\
\hline 44 & .072 & .025 & .052 & .019 & .033 & .008 \\
\hline 45 & .082 & .031 & .066 & .024 & .037 & .010 \\
\hline 46 & .093 & .042 & .067 & .027 & .040 & .011 \\
\hline 47 & .105 & .054 & .077 & .035 & .048 & .014 \\
\hline 48 & .119 & .063 & .089 & .041 & .051 & .017 \\
\hline 49 & .134 & .078 & .103 & .050 & .058 & .020 \\
\hline 50 & .151 & .092 & .115 & .065 & .065 & .026 \\
\hline 51 & .171 & .097 & .131 & .078 & .072 & .031 \\
\hline 52 & .193 & .116 & .146 & .096 & .080 & .042 \\
\hline 53 & .218 & .137 & .169 & .113 & .090 & .053 \\
\hline 54 & .246 & .162 & .190 & .132 & .101 & .064 \\
\hline $\begin{array}{l}55 \\
56\end{array}$ & .278 & .196 & $\begin{array}{l}.218 \\
-0- \\
.099\end{array}$ &. .156 & -.115 & $\begin{array}{c}.078 \\
-.061\end{array}$ \\
\hline 57 & & & .101 & .128 & .080 & .068 \\
\hline 58 & & & .111 & .143 & .079 & .079 \\
\hline 59 & & & .107 & .147 & .077 & .085 \\
\hline 60 & & & .100 & .148 & .073 & .094 \\
\hline 61 & & & .096 & .105 & .076 & .071 \\
\hline 62 & & & .090 & .095 & .066 & .074 \\
\hline 63 & & & & & .054 & .073 \\
\hline 64 & & & & & .047 & .074 \\
\hline 65 & & & & & .032 & .073 \\
\hline
\end{tabular}

a Plans with early or normal retirement supplements are excluded. 
about 8 percent. Second, the discontinuity in accrual ratios at the age of early retirement is much larger for plans without a social security offset than for plans with an offset. For example, among plans with normal retirement at age 62 , there is a 55 percent drop in the accrual ratio between ages 55 and 56 , while for plans with a social security offset the drop is about 17 percent. The smaller reduction in the accrual ratio at 55 for these social security offset plans appears to be explained as follows. Because workers experience faster wage growth prior to their mid-fifties, their social security Primary Insurance Amount, a key determinant of the benefit offset, grows at a faster rate for younger workers. This factor plus the ceilings on the offset amount established by many of these plans means that social security offsets reduce accrual ratios prior to a worker's mid-fifties by a greater percentage than after his/her mid-fifties. As a consequence, the reduction in the accrual ratio at age 55 is proportionally smaller in offset plans than in non-offset plans.

To demonstrate the wide variation among plans with the same early and normal retirement ages, we have reproduced in table 7 the accrual ratios for plans with normal retirement at 55 and early retirement at 65 , together with the minimum and maximum accruals among these plans for each age. Almost half of the plans have these early and normal retirement ages. The average accrual ratios, as noted above, rise to about 10 percent by the age of early retirement and then fall to about 5 percent by the age of normal retirement at 65 . But there is a very large variation among the plans. In particular, a large number of plans 
Table 7. Welghted average and $\mathrm{minlmum}$ and maximum accrual rates for percent of earnings plans, with 10-year cllff vestling with early retirement at 55 and normal retirement of $65^{\circ}$

\begin{tabular}{|c|c|c|c|}
\hline Age & Aver age & Min imum & Maximum \\
\hline 40 & .069 & .000 & .388 \\
\hline 41 & .013 & -.025 & .072 \\
\hline 42 & .016 & -.025 & .081 \\
\hline 43 & .018 & -.027 & .092 \\
\hline 44 & .020 & -.026 & .104 \\
\hline 45 & .023 & -.079 & .118 \\
\hline 46 & .026 & -.028 & .133 \\
\hline 47 & .031 & -.025 & .164 \\
\hline 48 & .034 & -.020 & .169 \\
\hline 49 & .040 & -.021 & .191 \\
\hline 50 & .046 & -.011 & .215 \\
\hline 51 & .052 & -.020 & .243 \\
\hline 52 & .062 & -.018 & .274 \\
\hline 53 & .072 & -.015 & .309 \\
\hline 54 & .083 & -.014 & .348 \\
\hline $\begin{array}{l}55 \\
56\end{array}$ & $--\frac{.097}{.071}$ & $\begin{array}{l}-.005 \\
--.- \\
-.065\end{array}$ & $-\frac{.409}{.431}-\cdots$ \\
\hline 57 & .074 & -.063 & .355 \\
\hline 58 & .079 & -.050 & .252 \\
\hline 59 & .081 & -.046 & .309 \\
\hline 60 & .083 & -.064 & .351 \\
\hline 61 & .074 & -.157 & .347 \\
\hline 62 & .070 & -.155 & .334 \\
\hline 63 & .063 & -.194 & .320 \\
\hline 64 & .060 & -.221 & .471 \\
\hline 65 & .052 & -.326 & .350 \\
\hline
\end{tabular}

a There are 528 plans. Plans with early or normal retirement supplements are excluded. 
exhibit negative rates of pension accrual after the age of early retirement, while others have much higher accrual ratios than the average. For example, at 65 the accrual ratios range from a low of a negative 33 percent to a high of about 35 percent. These differences highlight the potential importance of joint consideration of wage rates and pension accruals, a task that we shall pursue in the future if appropriate data can be obtained.

Table 8 shows how average accrual râtios vary across industries. An important difference among the five industry groups is the proportion with specific early and normal retirement ages. Approximately 60 percent of plans in manufacturing have early retirement at 55 and normal retirement at 65 , while in retail trade more than 90 percent are in this group. Over 60 percent of plans in manufacturing on the other hand have early retirement as well as normal retirement at 55. Very few plans in retail trade, finance, or services have normal retirement at 55.

Plans with early and normal retirement at 55 have approximately the same weighted average accrual patterns in each of the industry groups, with a spike at vesting close to 25 percent and the accrual ratio at 55 ranging between 20 and 27 percent. The typical plan with normal retirement at age 62 exhibits a substantial drop in the accrual ratio at the early retirement age of 55 . The drop is about 35 percent in manufacturing and in finance and over 50 percent in transportation.

Plans with normal retirement at 65 . typically exhibit an accrual pattern that is much flatter than the pattern exhibited by the other plans in each 


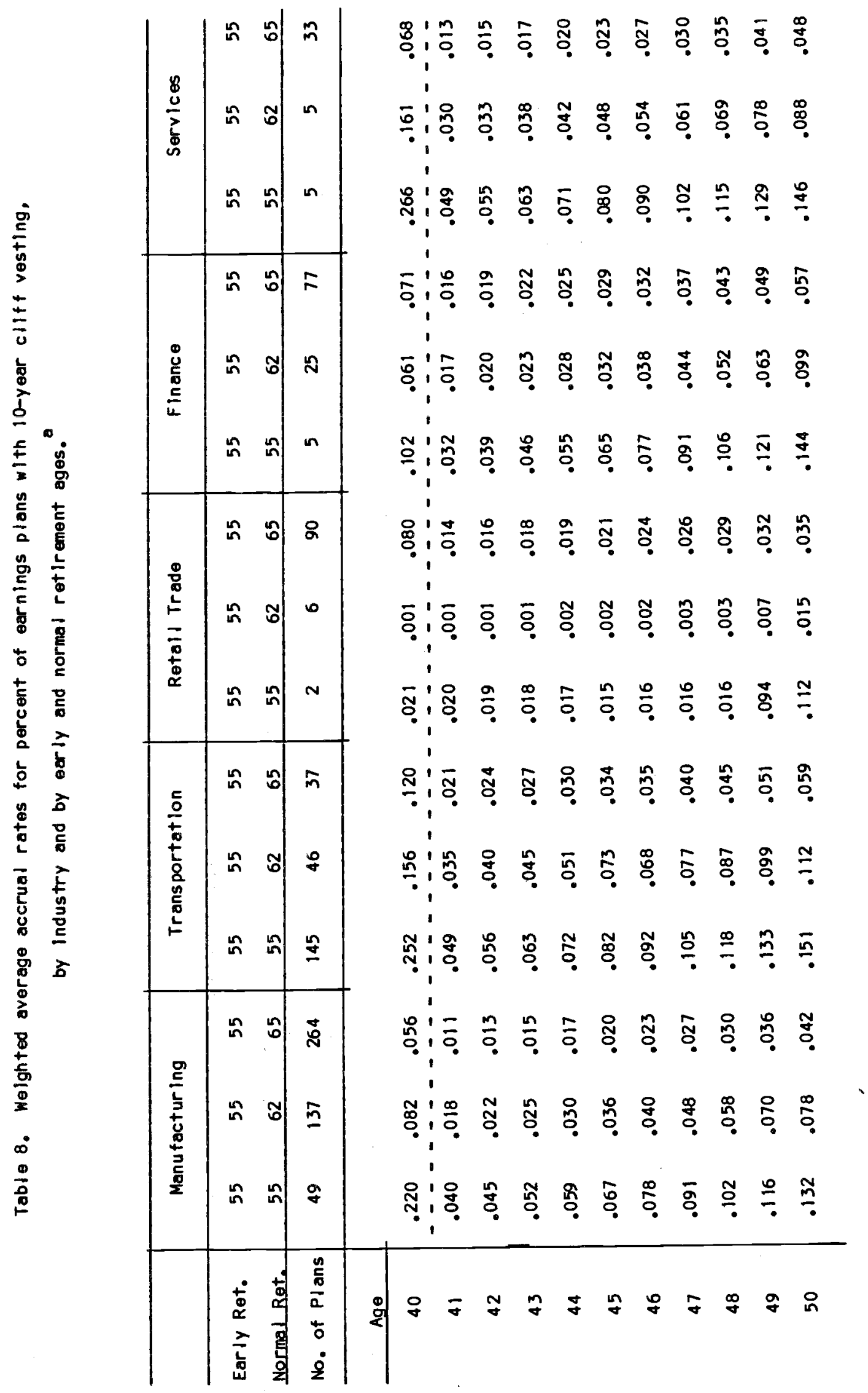




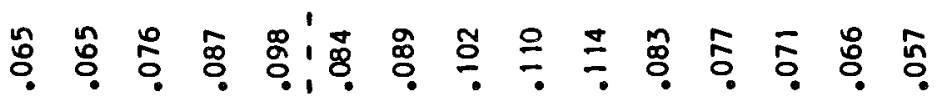

$$
\begin{aligned}
& \text { ชั } \\
& \text { 苯 }
\end{aligned}
$$

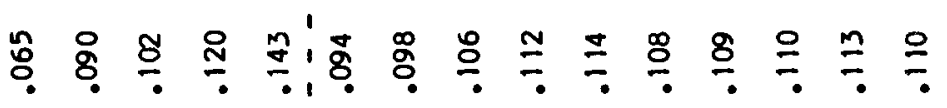

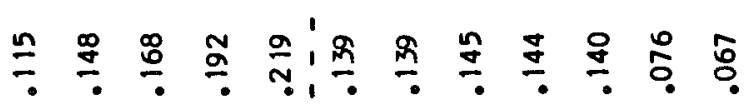

$$
\begin{aligned}
& \text { ถุด }
\end{aligned}
$$

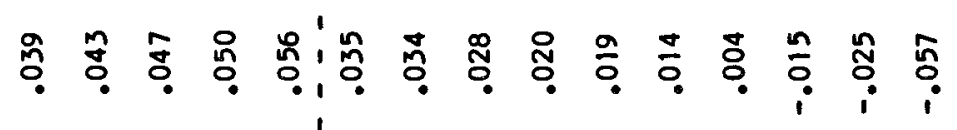

$$
\begin{aligned}
& \text { 芷 } \\
& \text { ำ ำ } \\
& \text { 马ำ } \\
& \text { ำำ } \\
& \text { ำำ }
\end{aligned}
$$

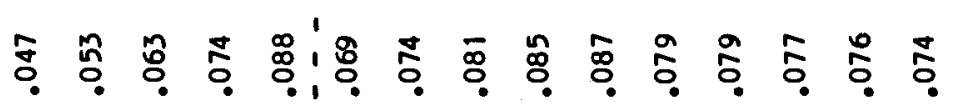

$$
\begin{aligned}
& \text { วัด }
\end{aligned}
$$

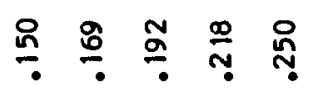

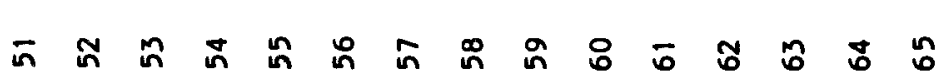


industry. These plans exhibit a drop in the accrual ratio at the age of early retirement that ranges from a low of 14 percent in services to a high of 35 percent in retail trade. The average accrual rate at 65 is minus 6 percent in retail trade and plus 11 percent in finance. It is approximately 6 percent in services and transportation and 7 percent in manufacturing.

Early and normal retirement supplements lead to widely varying accrual patterns and we have not tried to summarize them here. We will, however; present details of these plans in a subsequent paper. We shall also describe in future work the accrual pattern of flat rate plans with benefits based only on years of service. Approximately 35 percent of the BLS-LOB pension plans weighted by coverage are of this type. They typically exhibit negative accrual ratios after the age of early retirement.

\section{B. Accrual Profiles and Job Change}

Job change can reduce pension benefits substantially. For 749 plans we calculated accrued benefits at age 65 for persons hired at 31,41 , and 51 . In these calculations, we assume that a person does not become vested in another plan prior to joining the firm. For each plan we calculate accrued benefits using the associated industry-occupation wage profiles, for each of the hiring ages. The comparison of benefits of persons hired at 31 with those hired at 41 and 51 is made in two ways. The first is to sum age 65 accrued benefits over all plans for each age of hire and calculate the ratio of the sum of the benefits if persons were hired at 41 (or 51) to the sum if the same persons 
were hired at 31. The second comparison is the average of the ratios calculated for each plan, with each ratio weighted by the number of persons covered by the plan. The results are shown in Table 9.

The aggregate benefits of persons hired at 51 are only about 50 percent of the benefits of those hired at 31 . Persons hired at 41 would accurmlate about 80 percent of the benefits of persons hired at 31 . There is little difference between plans with and without a social security offset, based on the weighted average of plan ratios. Variation among occupations is not striking, but there is substantial variation across industries. Benefits if hired at 51 range from only 31 percent of the benefits if hired at 31 in retail trade, to 78 percent in manufacturing. The ratio if hired at 41 ranges from 65 percent in retail trade to 95 percent in transportation.

Thus job change can impose a very large cost in pension benefits. While these calculations do not incorporate vesting on one job before changing to another, we believe that such calculations -- more in line with the illustrations in section I -- would not substantially alter the order of magnitude of the benefit losses. Because we used accrued benefits at age 65 , the calculations also incorporate some negative accruals after the age of early retirement. It may be more appropriate to use maximum accrued benefits for each age of hire. 
Table 9. Accrued Beneflts at Age 65 for Persons Hired at

Age 41 and 51, as Percent of the Beneflts of

Persons Hired at Age 31

\begin{tabular}{|c|c|c|}
\hline $\begin{array}{l}\text { Plans Included and Age } \\
\text { When HIred and (Number } \\
\text { of Plans) }\end{array}$ & $\begin{array}{l}\text { Ratlo of the Sum } \\
\text { of Benefits }\end{array}$ & $\begin{array}{l}\text { Welghted Average } \\
\text { of the Plon Ratlos }\end{array}$ \\
\hline $\begin{array}{l}\text { Afl plans }(749) \\
\text { Hired at } 41 \\
\text { Hired at } 51\end{array}$ & $\begin{array}{l}.82 \\
.54\end{array}$ & $\begin{array}{l}.89 \\
.62\end{array}$ \\
\hline \multicolumn{3}{|l|}{$\begin{array}{l}\text { Plans without soclal } \\
\text { security of fset }(488)\end{array}$} \\
\hline $\begin{array}{l}\text { Hired at } 41 \\
\text { Hired at } 51\end{array}$ & -- & $\begin{array}{l}.79 \\
.50\end{array}$ \\
\hline \multicolumn{3}{|c|}{$\begin{array}{l}\text { Plans with soclal securlty } \\
\text { of tset (261) }\end{array}$} \\
\hline $\begin{array}{l}\text { Hired at } 41 \\
\text { Hired at } 51\end{array}$ & -- & $\begin{array}{l}.86 \\
.52\end{array}$ \\
\hline \multicolumn{3}{|l|}{ Mlning (20) } \\
\hline $\begin{array}{l}\text { HIred ot } 41 \\
\text { HIred at } 51\end{array}$ & .83 & -- \\
\hline \multicolumn{3}{|l|}{ Construction (7) } \\
\hline $\begin{array}{l}\text { Hired at } 41 \\
\text { Hired at } 51\end{array}$ & $\begin{array}{l}.79 \\
.48\end{array}$ & -- \\
\hline \multicolumn{3}{|l|}{ Manufacturing (346) } \\
\hline $\begin{array}{l}\text { Hired at } 41 \\
\text { Hired at } 51\end{array}$ & $\begin{array}{l}.80 \\
.50\end{array}$ & $\overline{--}$ \\
\hline \multicolumn{3}{|l|}{ Transportation ( 86$)$} \\
\hline $\begin{array}{l}\text { Hired at } 41 \\
\text { Hired at } 51\end{array}$ & $\begin{array}{l}.95 \\
.78\end{array}$ & $\overline{-}$ \\
\hline \multicolumn{3}{|l|}{ Wholesale Trade (25) } \\
\hline $\begin{array}{l}\text { HIred at } 41 \\
\text { HIred at } 51\end{array}$ & $\begin{array}{l}.83 \\
.57\end{array}$ & -- \\
\hline \multicolumn{3}{|l|}{ Retail Trade (127) } \\
\hline $\begin{array}{l}\text { Hired at } 41 \\
\text { Hired at } 51\end{array}$ & $\begin{array}{r}.65 \\
.31\end{array}$ & -- \\
\hline \multicolumn{3}{|l|}{ Finance $(100)$} \\
\hline $\begin{array}{l}\text { Hired at } 41 \\
\text { Hired at } 51\end{array}$ & $\begin{array}{l}.84 \\
.50\end{array}$ & -- \\
\hline Services (38) & & \\
\hline $\begin{array}{l}\text { Hired at } 41 \\
\text { Hired at } 51\end{array}$ & $\begin{array}{l}.90 \\
.57\end{array}$ & -- \\
\hline
\end{tabular}


IV. Concluding Comments

In our view the magnitude, patterns, and variations in pension accrual ratios are strikingly at odds with the view of spot clearing in labor markets. While market clearing in longer term contracts seems the only equililbrium theory consistent with these findings, it strains our credulity to ascribe optimizing behavior to the choice of pension accrual profiles. It seems much more likely that employees and employers rough tune rather than fine tune in their choice of pension plans, if there is any tuning whatsoever.

In our future research we intend to examine the ratio of accrued vested benefits to straight wages after the age of normal retirement. Preliminary evidence suggests very sizeable potential work disincentives after the normal retirement age because of a sharp decline in pension benefit accrual. We will also focus on the particular plan features having the greatest effect on accrual profiles. Plans with non-earnings related benefit formulas as well as plans with early and normal retirement supplemental benefits will also be studied. Given the appropriate data, we wish to investigate the relationship between individual earnings profiles and associated pension plans. In particular, we would like to know the extent to which wages adjust in accordance with pension plan provisions. A second important issue is the extent to which pension accrual patterns affect retirement decisions as well as turnover prior to vesting, early retirement, and normal retirement. 


\section{Footnotes}

1. We thank Gary Heaton for masterful and very extensive computer programming and Douglas Phillips for excellent research assistance.

2. This assumes no other explicit or implicit fringe benefits.

3. We are hopeful that the Department of Labor's extremely valuable survey of Private Pension Benefit Amounts will be released in the near future.

4. Bulow (1979) appears to be the first discussion of these discontinuities. Lazear (1981, 1983) presents empirical analysis of this issue.

5. The BLS-LOB survey contains 3248 plans of which the BLS labelled 2492 as "usable." Our master sample consists of 2343 of these 2492 plans, although this study only examines 1183 plans.

6. Pensions in the American Econoryy, Table 4.5.1.

7. Pensions in the American Econory, Table 3.6.5.

8. We make no use here of the truncated earnings data contained in the RHS social security earnings records.

9. The 1183 earnings based plans with cliff vesting account for 51 percent of plans weighted by pension coverage. 


\section{$\underline{\text { References }}$}

Bulow, J. 1979. Analysis of pension funding under ERISA. NBER Working Paper no. 402 .

Lazear, E. P. 1983. Pensions as severance pay. Chapter three in Financial Aspects of the United States Pension System, Zvi Bodie and John B. Shoven eds., Chicago: University of Chicago Press.

Lazear, E. P. 1981. Severance pay, pensions, mobility, and the efficiency of work incentives. Mimeo, University of Chicago.

Kotlikoff, L. J., and Smith, D. E. 1983. Pensions in the American Economy.

National Bureau of Economic Research. Chicago: University of Chicago Press. 